\title{
Uncommon Subtypes of Malignant Melanomas: A Review Based on Clinical and Molecular Perspectives
}

\author{
Matías Chacón *, Yanina Pfluger, Martín Angel $\mathbb{D}^{\mathbb{D}}$, Federico Waisberg ${ }^{+} \mathbb{D}$ and Diego Enrico ${ }^{+}$ \\ Department of Medical Oncology, Alexander Fleming Cancer Institute, Buenos Aires 1426, Argentina; \\ ypfluger@alexanderfleming.org (Y.P.); mangel@alexanderfleming.org (M.A.); \\ fwaisberg@alexanderfleming.org (F.W.); denrico@alexanderfleming.org (D.E.) \\ * Correspondence: mchacon@alexanderfleming.org; Tel.: +54-11-3221-8900 \\ t These authors contributed equally to this work.
}

Received: 30 June 2020; Accepted: 29 July 2020; Published: 21 August 2020

\begin{abstract}
Malignant melanoma represents the most aggressive type of skin cancer. Modern therapies, including targeted agents and immune checkpoint inhibitors, have changed the dismal prognosis that characterized this disease. However, most evidence was obtained by studying patients with frequent subtypes of cutaneous melanoma (CM). Consequently, there is an emerging need to understand the molecular basis and treatment approaches for unusual melanoma subtypes. Even a standardized definition of infrequent or rare melanoma is not clearly established. For that reason, we reviewed this challenging topic considering clinical and molecular perspectives, including uncommon CMs-not associated with classical V600E/K BRAF mutations-malignant mucosal and uveal melanomas, and some unusual independent entities, such as amelanotic, desmoplastic, or spitzoid melanomas. Finally, we collected information regarding melanomas from non-traditional primary sites, which emerge from locations as unique as meninges, dermis, lymph nodes, the esophagus, and breasts. The aim of this review is to summarize and highlight the main scientific evidence regarding rare melanomas, with a particular focus on treatment perspectives.
\end{abstract}

Keywords: rare melanomas; uncommon melanomas; targeted therapy; immunotherapy; mucosal melanoma; uveal melanoma; amelanotic melanoma; desmoplastic melanoma; spitzoid melanoma; acral melanoma

\section{Introduction}

Malignant melanoma is one of the most aggressive cancers once it becomes metastatic, thus an early identification has a high impact on prognoses. In less than ten years, melanoma has become a successful model where preclinical and clinical advances in research could provide meaningful improvements on patients' survival and quality of life. Melanoma was one of the first tumor models where targeted agents and immunotherapy have revolutionized patient outcomes. However, most of this scientific progress focused mainly on studying patients with cutaneous melanoma (CM), representing the most common subtype.

Rare melanoma variants usually account for less than $5 \%$ of all melanomas, and often are associated with a poor prognosis [1-3]. Of note, the molecular basis and treatment approaches for patients with unusual melanomas are still not elucidated. Furthermore, a uniform definition of these "rare melanomas" has not been clearly established. Our review provides an overview of the clinical, biological, and mutational landscapes of rare melanoma subtypes, summarizing the most relevant evidence on therapeutic approaches. 


\section{Cutaneous Melanoma}

\subsection{Introduction}

CM represents the most lethal and frequent type of skin cancer. Between $40 \%$ and $60 \%$ of CMs harbor activating $B R A F$ mutations, characterized by the substitution of the valine residue at position 600 by glutamate (V600E) or lysine (V600K), representing 70-90\% and 10-20\% of somatic alterations of this gene, respectively [4-7]. The determination of molecular predictive factors has become essential for treatment definitions in patients diagnosed with stage III or IV CM. A dual MEK/BRAF blockade in patients harboring BRAF V600E/K mutant CMs has resulted in significant improvements in the overall survival (OS) in the adjuvant and advanced settings [8,9]. Immune checkpoint inhibitors have also been established as an effective treatment for CM, showing significant increases in recurrence-free survival, progression-free survival (PFS) and the OS in the same scenarios [10-12]. In pivotal trials, these results were evident in all biomarker-oriented analyzed subgroups, regardless of mutational status.

In light of current evidence, immune checkpoint inhibitors are considered a standard treatment for patients with $\mathrm{CM}$, and BRAF/MEK inhibitors are recommended in patients with melanoma and BRAF V600E/K mutations [10-12].

In the following section, we will summarize CM's clinical characteristics and treatment approaches not associated with specific therapeutic strategies. First, we will review current evidence of biomarker-oriented subgroups, considering CM's genomic classification defined by The Cancer Genome Atlas Network (NRAS, BRAF, NF1, triple wild-type subgroups) [13]. Tumors with BRAF $\mathrm{V} 600 \mathrm{E} / \mathrm{K}$ mutations will not be addressed in our review due to the fact that treatment strategies are based on phase 3 clinical trials that had evaluated this population. Secondly, we will describe the clinical features and treatment approaches in special morphological entities, such as amelanotic, desmoplastic, spitzoid, and acral melanomas. All these entities were underrepresented in pivotal practice-changing trials. In each subsection, clinical characteristics and relevant published studies will be addressed (Figure 1).

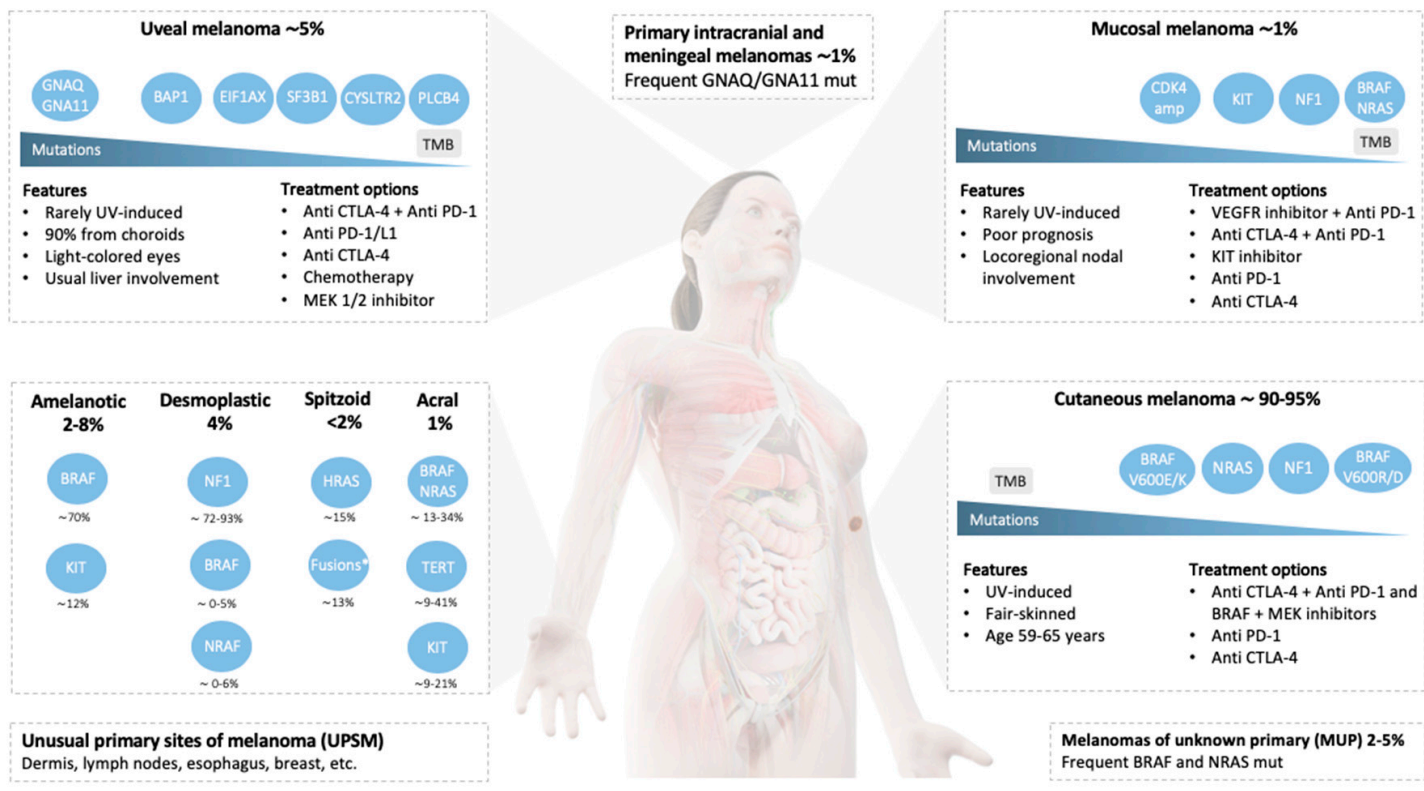

Figure 1. Schematic summary of the most relevant mutations, key features, and treatment options of rare melanomas. For each subtype, mutations are ordered by their prevalence. Main treatment strategies were ordered according to the decreasing efficacy outcomes, including the overall response rate, progression-free survival, and overall survival. Abbreviations: TMB, tumor mutational burden; UV, ultraviolet radiation; Mut, mutation; Amp, amplification; KIT, receptor tyrosine kinase (c-Kit); VEGFR, vascular endothelial growth factor receptor. *Fusion kinases involving ALK, ROS1, NTRK1, NTRK3, MET, RET, BRAF, and MAP3K8. 


\subsection{Genetic Landscape and Specific Treatment Approaches}

\subsubsection{NRAS}

NRAS gene mutations contribute to the activation of mitogen-activated protein kinase (MAPK) pathway signaling, inducing melanocytogenesis, and increasing cell proliferation and survival. It is estimated that up to $25 \%$ of CMs harbor NRAS gene alterations, $80 \%$ of these being Q61R, Q61K, and Q61L point mutations [14].

Primary lesions in this subtype are associated with clinical features such as ulceration, high levels of Breslow depth, an increased mitotic rate, and chronic ultraviolet exposure [15]. Particularly, NRAS mutations were found in $21 \%$ of superficial spreading, $31 \%$ of nodular and $8 \%$ of acral melanoma subtypes, and they are frequent among patients older than 55 years [16,17]. Of note, advanced NRAS-mutant diseases have been associated with central nervous system involvement at diagnosis [14]. The response rates and duration of responses for targeted therapy in patients with NRAS-mutant melanoma have proven to be modest. Selected studies are described in Table 1.

Table 1. Selected NRAS-mutant melanoma clinical trials.

\begin{tabular}{|c|c|c|c|c|c|c|c|}
\hline Study & Phase & $N$ & Arms & $\begin{array}{c}\text { ORR } \\
(\%)\end{array}$ & $\begin{array}{c}\text { DCR } \\
(\%)\end{array}$ & $\begin{array}{l}\text { PFS } \\
\text { (mo) }\end{array}$ & $\begin{array}{c}\mathrm{OS} \\
(\mathrm{mo})\end{array}$ \\
\hline Dummer et al. 2017 [18] & $3^{\mathrm{a}, \mathrm{e}}$ & 402 & $\begin{array}{l}\text { Binimetinib; } \\
\text { Dacarbazine }\end{array}$ & $15 ; 7$ & $58 ; 25$ & $2.8 ; 1.5$ & $11 ; 10.1$ \\
\hline Lebbe et al. 2016 [19] & $2^{b, e}$ & 194 & $\begin{array}{l}\text { Pimasertib; } \\
\text { Dacarbazine }\end{array}$ & $27 ; 14$ & $33 ; 16$ & $3.3 ; 1.7$ & $\begin{array}{r}8.9 \\
10.6\end{array}$ \\
\hline Ascierto et al. 2013 [20] & $2^{d}$ & 30 & Binimetinib & 10 & 63 & 3.7 & NS \\
\hline Kirkwood et al. 2012 [21] & $2^{c, e}$ & $10 ; 18$ & $\begin{array}{l}\text { Selumetinib; } \\
\text { Temozolomide }\end{array}$ & $0 ; 6$ & $50 ; 55$ & NS & NS \\
\hline Kim et al. 2019 [22] & $1^{\mathrm{e}}$ & 9 & Belvarafenib & 44 & NS & 6.2 & NS \\
\hline Schuller et al. 2017 [23] & $1 b^{e}$ & 16 & $\begin{array}{l}\text { Ribociclib + } \\
\text { Binimetinib }\end{array}$ & 25 & 69 & 6.7 & NS \\
\hline Algazi et al. 2017 [24] & $1^{\mathrm{d}, \mathrm{e}}$ & 10 & $\begin{array}{c}\text { GSK } 2141795^{\mathrm{f}}+ \\
\text { Trametinib }\end{array}$ & 0 & 40 & 2.3 & 4 \\
\hline Sullivan et al. 2017 [25] & $1^{\mathrm{e}}$ & 18 & Ulixertinib & 17 & NS & NS & NS \\
\hline Falchook et al. 2012 [26] & $1^{\mathrm{b}, \mathrm{e}}$ & 7 & Trametinib & 0 & 22 & NS & NS \\
\hline
\end{tabular}

Abbreviations: ORR, overall response rate; DCR, disease control rate; PFS, progression-free survival; OS, overall survival; NS, not specified. a Analysis of patients with cutaneous melanoma or melanoma with an unknown primary; ${ }^{b}$ analysis of patients with cutaneous melanoma; ${ }^{c}$ analysis of patients with cutaneous and mucosal melanoma or melanoma with an unknown primary; ${ }^{\mathrm{d}}$ analysis of patients with cutaneous and mucosal melanoma.;

${ }^{\mathrm{e}}$ results shown only for patients with NRAS mutations; ${ }^{\mathrm{f}} \mathrm{AKT}$ inhibitor.

In the advanced setting, immune checkpoint inhibitors, such as monotherapy or in combination, remain the main therapeutic strategies. Kirchberger and collaborators retrospectively analyzed 364 patients with advanced melanoma who received immunotherapy. The authors found that the response rates among patients with and without NRAS mutations were similar (31\% vs. $26 \%$ for the anti-PD-1/anti-CTLA- 4 combination and $21 \%$ vs. $13 \%$ for the anti-PD-1 monotherapy, respectively) [27]. Interestingly, a better response rate with immunotherapy combination was observed in patients with Q61L NRAS mutations. A trend of superior PFS was also evidenced in subjects with a Q61L NRAS-mutant disease in another retrospective analysis [28]. With the current evidence, the combination of immune checkpoint inhibitors is the common first treatment approach for patients with tumors harboring this mutation.

Ongoing clinical trials are evaluating novel MEK inhibitors (FCN-159), pan-RAF therapies (belvarafenib), a combination of MEK inhibitors and therapies that target other relevant mechanisms, such as autophagy (hydroxychloroquine) and immune checkpoint inhibitors [22,29-31]. Areas of 
further investigation include the inhibition of enzymes that are overexpressed in NRAS-mutant melanoma, including polo-like kinase, ROCK1/2, and Tand-binding kinase 1 [32]. Moreover, Dinter and collaborators have suggested a potential role of the combination of MEK and BRAF inhibitors, due to the increased levels of endoplasmic reticulum stress detected in NRAS-mutant melanoma cell lines [33].

\subsubsection{NF1}

Representing around 15\% of CM cases, NF1 loss leads to decreased RAS-GTP dephosphorylation, resulting in an increase in RAS-GTP and subsequently RAF-MEK-ERK phosphorylation [13].

NF1 mutations are particularly frequent in patients of an older age. Additionally, the associated clinical features include chronic sun exposure, desmoplastic melanoma, UV mutational signatures, and a high tumoral mutation burden [34]. Notably, in patients with neurofibromatosis, type 1 melanoma risk is only increased by 3.6-fold [35].

Importantly, Garman and collaborators, after characterizing 30 NF1 mutant tumor biopsies, patient-derived xenografts and cell lines, documented the coexistence of non-V600E BRAF, RAS, and other characteristic MAP kinase-associated genes mutations in $87 \%$ of the analyzed cases. This finding is in accordance with functional studies that documented that not all NF1 mutant cell lines were sensitive to MEK inhibitors [36]. Therefore, a further characterization of the NF1 mutant subgroup is needed, considering the occurrence of concurrent mutations.

Immunotherapy remains the main strategy for this subgroup of patients. In a study performed by Eroglu et al., among 17 evaluable patients with desmoplastic melanoma, 14 harbored NF1 alterations. Considering the high overall response rate (ORR) observed in this histologic subgroup, a benefit of checkpoint inhibitors is expected in patients with CM and NF1 mutations [37] and is the principal treatment option for this population.

\subsubsection{Uncommon BRAF Mutations}

Pivotal studies that determined the approval of available target combinations did not include subjects with gene alterations, apart from V600E and V600K [9,38]. Consequently, the therapeutic implications in this population have mostly been assessed in retrospective studies.

V600R represents 5-7\% of BRAF mutations, constituting the third most frequent alteration. Comparable to patients with melanoma and V600K mutations, V600R alterations are more prevalent in men and older patients [39]. Regular characteristics include tumor ulceration, primary localizations associated with cumulative sun-induced DNA damage, and short disease-free intervals between the primary diagnosis and the occurrence of distant lesions [40,41]. Menzer and colleagues described the results of the largest multicenter retrospective study that included patients with uncommon BRAF mutations [42]. Notably, among 26 patients with $B R A F$ V600R mutations, a significant improvement in the median OS (22.9 vs. 7.3 months, $p=0.002)$, median PFS ( 8.0 vs. 3.8 months, $p=0.002)$ and ORR (57 vs. $22 \%$ ) was observed when MEK inhibitors were administrated together with BRAF inhibitors in comparison to the group that was only assigned to the treatment with BRAF inhibitors. Less information is available regarding other BRAF codon 600 mutations. According to Menzer and colleagues' study, a tumoral response with BRAF or BRAF/MEK inhibition was observed in patients that harbored BRAF V600D (four of five) and V600M mutations (one of two). All seven cases were associated with clinical benefits. Although further study is needed, these results support that BRAF and MEK inhibition is an effective strategy for patients with melanoma and uncommon codon 600 BRAF mutations.

Unlike non-small cell lung cancer, BRAF mutations that do not affect codon 600 (non-600) are particularly infrequent in melanoma. A higher prevalence of this alteration is observed in patients with head and neck melanomas.

In this group, mutations could be characterized regarding the kinase activity. In a recent report published by Lokhandwala and collaborators, class II mutations (RAS-independent kinase-activating 
dimers not involving codon 600), such as L597Q/R/S, K601E and G469A/R/V, represented 7.4\% of cases with BRAF mutations. Class III mutations (associated with a low BRAF activity) were observed in $12 \%$ of BRAF-mutant patients. Examples of the latter include G466A/E/V, S467L, N581I, and D594E/G/N [43].

Menzer and colleagues observed that only two out of nine patients with codon 597 and one out of four patients with K601E mutations presented tumoral responses with dual inhibition [42]. Contrastingly, two of the three patients with codon 469 alterations achieved a tumor response.

While the efficacy of target therapies in patients with BRAF class II mutations is still unclear, the National Comprehensive Cancer Network (NCCN) guidelines consider BRAF/MEK inhibition as a recommended strategy for patients with L597 and 601 BRAF mutations [44].

\subsubsection{Actionable Mutations in the Triple Wild-Type Subgroup (No Mutations in BRAF, RAS, or NF1)}

Tumor-agnostic drug approvals offer a window of opportunity for melanoma patients. In this context, kinase fusions, including $A L K, R E T, R O S 1, B R A F$, and NTRK, are characteristic of Spitz melanomas.

Including all CM subtypes, Busam and collaborators have performed immunohistochemistry for $A L K$ detection in 603 samples of metastatic and primary tumors [45]. Nine metastatic tumors (3\%) and seven primary CMs (2.3\%) were classified as ALK-positive. Notably, after performing RNA sequencing, positive samples presented an isoform associated with alternative transcriptional initiation (ATI) sites.

Concomitantly, Lezcano and collaborators have identified among 751 analyzed melanoma samples, four cases with NTRK fusions. Interestingly, all four cases presented epitheloid cell figures and were amelanotic [46].

Gene fusions and chromosomic translocations were also evidenced in patients with acral melanoma. For instance, Niu and colleagues have determined the ALK breakpoints in 4 of 28 samples of patients with acral melanoma [47]. Additionally, in the context of the STARTRK-1 trial, a GOPC-ROS1 fusion was identified in 1 out of 22 patients with this melanoma subtype. This individual was reported to achieve a partial response that lasted at least 11 months with entrectinib. Moreover, a patient with an acral melanoma and a RET fusion was reported by Turner and colleagues [48].

KIT signaling plays an essential role in the development of melanocytes, as demonstrated in infrequent genetic disorders associated with hypopigmentation, such as piebaldism. While in NRAS- or BRAF-mutant melanomas, there are increased levels of KIT promoter hypermethylation. It has been classically estimated that around $2-8 \%$ of melanomas that arise within cumulative sun-damaged skin exhibit KIT gene mutations $[49,50]$. The efficacy with KIT-directed therapies was modest, as further discussed in the mucosal melanoma section. While immunotherapy is the principal therapeutic approach in these patients, the possibility of defining targetable mutations associated with tumor responses in other cancer models supports the need of further characterization of the "triple wild-type" subgroup.

\subsection{Entities with Special Morphology}

\subsubsection{Amelanotic Melanoma}

Amelanotic/hypomelanotic melanoma (AM) is a clinicopathological subtype of CM characterized by a decreased or null presence of melanin due to the loss of pigment in tumor evolution, presenting between $2 \%$ and $8 \%$ of total cases [51]. Due to late recognition, this melanoma subtype is usually diagnosed at more advanced stages, which may explain why patients diagnosed with this entity have a shorter OS compared to CM patients [52]. Other clinical common features of this entity include mostly associations with older age and primary localizations with previous sun exposure, such as the head and neck, trunk, and lower limbs [53]. Interestingly, AM is commonly observed in patients with melanocortin 1 receptor gene $(M C 1 R)$ genotypes linked to particular phenotypes, including red hair color $[54,55]$. 
The mechanism underlying amelanosis is still unclear. Although previous studies considered AM as de-differentiated or poorly differentiated melanoma, AM cells maintain the melanocytic lineage and melanin-forming ability, which is demonstrated by tyrosinase and microphthalmia-associated transcription factor (MITF) expression [53,56-58]. In this context, AM may result from the insufficient activity of specific melanin formation enzymes, such as tyrosinase $[59,60]$. Notably, germline mutations in genes for MC1R, MITF, and $p 14 A R F$ may also result in AM [55,61,62].

The incidence of target mutations in AM has been scarcely characterized. By conducting a sequencing analysis of 33 AM patients, Massi et al. found a BRAF V600E and KIT mutations rate of $70.3 \%$ and $12.1 \%$, respectively [63]. The authors evidenced that KIT aberrations were relatively higher in amelanotic lesions in comparison to pigmented primaries.

Considering these findings, BRAF mutation analysis in AM may be considered as a potentially valuable diagnostic tool. As with other $\mathrm{CM}$ variants, treatment strategies include immune checkpoint inhibitors and the combination of BRAF/MEK inhibitors in the cases where BRAF mutations are present.

\subsubsection{Desmoplastic Melanoma}

Desmoplastic melanoma (DM) is an uncommon variant (4\%) characterized by spindle cells and dense scar-like fibrosis. Histologically, it may resemble other spindle cell lesions of the skin, including spindle cell squamous cell carcinoma, atypical fibroxanthoma, spindle cell sarcoma, and malignant peripheral nerve sheath tumors. Although the S100 stain is usually present, other melanoma markers (HMB-45 and Melan-A) are often negative. SOX10 expression has been shown to be a sensitive and specific marker of DM [64].

Sun exposed areas are commonly affected, and around $60 \%$ of lesions are described as non-pigmented, which frequently delays diagnosis [65]. However, DMs are associated with a lower risk of distant metastases in comparison to classic CM [66].

Hotspot mutations in BRAF or NRAS are not common in DM $(0-6 \%)[34,67]$. Though, other alterations in genes related to the MAPK pathway are frequently observed, including NF1, CBL, ERBB2, MAP2K1, and MAP3K1. Amplifications in EGFR, CDK4, MDM2, TERT, MAP3K1, MET, NFKBIE, and $Y A P 1$ are also commonly found in this melanoma subtype $[34,67,68]$.

DM has been associated with UV-induced DNA alterations, presenting a mutation rate four-fold higher than classic CM [67]. Not surprisingly, Boussemart and colleagues found an average tumor mutational burden (TMB) of 77 mut/MB in 12 cases of DM, in comparison to an average TMB of 35 mut/MB obtained after analyzing 1228 samples of other melanoma variants [69]. Consequently, immune checkpoint inhibitors represent a promising strategy in this setting. In a retrospective analysis, Eroglu et al. reported a 70\% ORR and 32\% complete response rate using anti PD-1/PDL-1 blockade in 60 patients with advanced DM, consolidating checkpoint inhibitors as a key treatment strategy in this particular subgroup [37].

\subsubsection{Spitzoid Melanoma}

These heterogeneous melanocytic tumors have distinctive histopathologic features, including Spitz nevi, atypical Spitz tumors, and Spitz melanomas. While Spitz tumors are especially frequent in children and adolescents (10-20 years), the incidence of spitzoid melanoma markedly increases in patients older than 20 years [70]. It should be highlighted that Spitz tumors mostly arise in the extremities and face, and lesions arising in other localizations should be carefully examined for a differential diagnosis. Spitz melanomas are characterized by a common regional lymph node spread. In contrast, distant metastases are rarely observed [71,72].

Spitz melanomas, according to the WHO 2018 classification, are defined by the presence of specific genetic hallmarks, such as HRAS mutations or fusions in activating genes, including BRAF, NTRK1, NTRK3, ROS1, ALK and MAP3K8 [73-75]. This characterization has led to distinguishing Spitz melanoma from other spitzoid malignant lesions. In this context, Raghavan and collaborators have documented that only $36 \%$ of 25 analyzed spitzoid melanomas were genetically defined as 
Spitz melanomas [76]. These considerations support that genetic profiling is essential for an accurate diagnostic assessment of this subtype [77].

There is scarce evidence regarding the clinical efficacy of targeted therapy in patients with spitzoid melanomas. A recent presentation highlighted that an 11-year-old patient with this tumor subtype and MAP3K8 fusion had a non-lasting response with the MEK inhibitor trametinib [78].

Although more information is needed to support specific recommendations, a biomarker-driven approach is reasonable in patients with this melanoma subtype. Treatment possibilities may include BRAF/MEK, ALK (crizotinib, certinib, alectinib), NTRK (entrectnib, larotrectinib) and ROS1 (crizotinib, ceritinib, entrectinib, lorlatinib) inhibitors. In addition, the mechanism of action of farnesyl transferase inhibitors, such as tipifarnib, may represent an interesting approach for patients with HRAS-mutant tumors [79].

\subsubsection{Acral Lentiginous Melanoma}

Acral lentiginous melanoma (ALM) represents only $1 \%$ of all melanomas in white populations, exhibiting a higher incidence among Africans, Asians, and descendants of Central Americans [80]. Typical localizations include palms, soles, and nail beds and are frequently characterized by a lentiginous growth pattern. The natural evolution of ALM lesions is slow and it often arises years before diagnosis. Clinical presentation is often observed after foot lesions or associated symptoms, including pain, bleeding, and itching. The advanced stage of the presentation at diagnosis is considered a key contributor to the poor prognosis of this entity.

The frequency of BRAF mutations in ALM is estimated to be between $13 \%$ and $34 \%[81,82]$. KIT mutations and/or amplifications are relatively more common and are present in approximately $9 \%$ to $21 \%$ of cases. Some phase 2 trials have evaluated the role of KIT inhibitors in this patient subgroup [83]. As described in Table 2, the outcomes in this subgroup were comparable to other melanoma subtypes, and the ORRs evidenced were around $14 \%$ to $38 \%$. Other therapeutic approaches are being explored in this rare subtype. Remarkably, 9-41\% of ALMs carry activating mutations in TERT promoters. Although point mutations cause TERT deregulation in UV-exposed melanomas, about $45 \%$ of ALMs have TERT copy number gains [84]. Telomerase inhibitors have been evaluated in cell lines, and patient-derived xenografts and tumor growth was especially suppressed in cases with TERT copy number gains [85]. The obtained results support the further evaluation of telomerase inhibition in patients with ALM.

Table 2. Selected clinical trials that assessed KIT inhibitors in melanoma.

\begin{tabular}{|c|c|c|c|c|c|c|c|c|}
\hline Study & Phase & $N$ & Subtype (n) & Arms & ORR (\%) & DCR (\%) & $\begin{array}{l}\text { PFS } \\
\text { (mo) }\end{array}$ & $\begin{array}{c}\text { OS } \\
(\mathrm{mo})\end{array}$ \\
\hline Kim et al. 2008 [86] & $2^{b}$ & 21 & $\begin{array}{c}\text { Cutaneous (7) } \\
\text { Acral (2) } \\
\text { Soft part (1) } \\
\text { Unclassified (11) }\end{array}$ & Imatinib & 4.8 & 23.8 & 1.4 & 7.5 \\
\hline Guo et al. 2011 [87] & $2^{a}$ & 43 & $\begin{array}{c}\text { Acral (21) } \\
\text { Mucosal (11) } \\
\text { Cutanous (9) } \\
\text { Unknown (2) }\end{array}$ & Imatinib & 23.3 & 53.5 & 3.5 & 14 \\
\hline Carvajal et al. 2011 [88] & $2^{\mathrm{a}}$ & 28 & $\begin{array}{c}\text { Mucosal (13) } \\
\text { Acral (10) } \\
\text { Cutaneous (5) }\end{array}$ & Imatinib & $\begin{array}{c}\text { Mucosal } 23 \\
\text { Acral } 38 \\
\text { Cutaneous } 0\end{array}$ & NS & 2.8 & 10.7 \\
\hline Hodi et al. 2013 [89] & $2^{a}$ & 24 & $\begin{array}{l}\text { Mucosal (17) } \\
\text { Acral (6) } \\
\text { Cutenous (1) }\end{array}$ & Imatinib & 29 & 50 & 3.7 & 12.5 \\
\hline Cho et al. 2012 [90] & $2^{a}$ & 11 & $\begin{array}{c}\text { Acral (9) } \\
\text { Mucosal (2) }\end{array}$ & Nilotinib & 22.2 & 77.8 & 2.5 & 7.7 \\
\hline Carvajal et al. 2015 [91] & $2^{a, e}$ & 19 & $\begin{array}{c}\text { Mucosal (12) } \\
\text { Acral (4) } \\
\text { Cutaneous (3) }\end{array}$ & Nilotinib & $\begin{array}{l}\text { Mucosal } 27.2 \\
\text { Acral } 0 \\
\text { Cutaneous } 0\end{array}$ & $\begin{array}{c}\text { Mucosal } 63.6 \\
\text { Acral } 25 \\
\text { Cutaneous } 33.3\end{array}$ & $\begin{array}{l}3.4^{f} \\
2.6^{g}\end{array}$ & $\begin{array}{l}14.2^{\mathrm{f}} \\
4.3^{\mathrm{g}}\end{array}$ \\
\hline
\end{tabular}


Table 2. Cont.

\begin{tabular}{|c|c|c|c|c|c|c|c|c|}
\hline Study & Phase & $N$ & Subtype (n) & Arms & ORR (\%) & DCR (\%) & $\begin{array}{l}\text { PFS } \\
\text { (mo) }\end{array}$ & $\begin{array}{c}\text { OS } \\
\text { (mo) }\end{array}$ \\
\hline Lee et al. 2015 [92] & $2^{b}$ & 27 & $\begin{array}{c}\text { Acral (15) } \\
\text { Mucosal (7) } \\
\text { Cutaneous (5) }\end{array}$ & Nilotinib & $\begin{array}{c}\text { Acral } 40 \\
\text { Mucosal } 0 \\
\text { Cutaneous } 0\end{array}$ & $\begin{array}{c}\text { Acral 73.3 } \\
\text { Mucosal } 28.6 \\
\text { Cutaneous } 40\end{array}$ & NS & NS \\
\hline Guo et al. 2017 [93] & $2^{b}$ & 42 & $\begin{array}{c}\text { Acral (20) } \\
\text { Mucosal (20) } \\
\text { Cutaneous (2) }\end{array}$ & Nilotinib & $\begin{array}{c}\text { Acral 25 } \\
\text { Mucosal } 25 \\
\text { Cutaneous } 50\end{array}$ & $\begin{array}{c}\text { Acral } 80 \\
\text { Mucosal } 70 \\
\text { Cutaneous } 50\end{array}$ & 4.2 & 18 \\
\hline Deylon et al. 2018 [94] & $2^{b}$ & 22 & $\begin{array}{c}\text { Mucosal (9) } \\
\text { Acral (7) } \\
\text { Cutaneous (6) }\end{array}$ & Nilotinib & $\begin{array}{c}\text { Mucosal } 33.3 \\
\text { Acral } 14.3 \\
\text { Cutaneous } 16.6\end{array}$ & $\begin{array}{c}\text { Mucosal } 66.6 \\
\text { Acral } 71.4 \\
\text { Cutaneous } 80\end{array}$ & $6^{\mathrm{d}}$ & $13.2^{\mathrm{d}}$ \\
\hline Kalinsky et al. 2016 [95] & $2^{b}$ & 25 & $\begin{array}{c}\text { Acral (15) } \\
\text { Mucosa (10) }\end{array}$ & Dasatinib & $\begin{array}{c}\text { Acral } 33 \\
\text { Mucosal } 14\end{array}$ & $50^{c}$ & 2.7 & 11.8 \\
\hline Minor et al. 2012 [96] & $-b$ & 6 & $\begin{array}{c}\text { Mucosal (NS) } \\
\text { Acral (NS) } \\
\text { Cutaneous (NS) }\end{array}$ & Sunitinib & $\begin{array}{c}\text { Mucosal } 60 \\
\text { Acral } 0\end{array}$ & $\begin{array}{c}\text { Mucosal } 60 \\
\text { Acral } 0\end{array}$ & NS & NS \\
\hline \multicolumn{9}{|c|}{$\begin{array}{l}\text { Abbreviations: ORR, overall response rate; DCR, disease control rate; PFS, progression-free survival; OS, overall } \\
\text { survival; NS, not specified. }{ }^{a} \text { Included patients with KIT amplifications; }{ }^{b} \text { only patients with KIT mutations; } \\
{ }^{c} \text { considering } 22 \text { patients in part II with KIT mutations; }{ }^{\mathrm{d}} \text { included three patients with KIT amplifications; }{ }^{\mathrm{e}} \text { after } \\
\text { prior treatment with imatinib; }{ }^{\mathrm{f}} \text { patients without central nervous system metastases; }{ }^{\mathrm{g}} \text { patients with central nervous } \\
\text { system metastases. }\end{array}$} \\
\hline
\end{tabular}

ALM has been reported to be less susceptible to immune checkpoint inhibitors than other common variants of CM [97]. Explanations of this fact include the low presence of tumor-infiltrating lymphocytes in ALM samples, a low somatic mutational burden, and the lack of a UV-mutational signature [98]. Nevertheless, small retrospective series showed similar tumor response rates when compared to CM $[99,100]$.

Under these circumstances, treatment recommendations in this subgroup include immune checkpoint inhibitors as the main therapeutic strategy. It should be highlighted that the NCCN guidelines describe that KIT inhibitors may be offered in patients with melanoma and activating KIT mutations [44]. As these agents are associated with non-lasting responses, treatment decisions should be carefully addressed on a case by case basis.

\section{Mucosal Melanoma}

\subsection{Introduction}

Mucosal melanoma (MM) is a highly infrequent ( $1 \%$ of all melanomas) and poor prognosis type of malignant melanoma, arising from melanocytes located in the internal epithelial of different tissues, such as nasopharyngeal, genitourinary, anorectal, and gastrointestinal mucosal membranes. Around half of MMs arise in the head and neck region, followed by the anorectum, and vulva [101].

Particularly, the five-year survival rate is less than $25 \%$ in this population, which may be explained by different factors, including the limitation of early visual detection compared to $\mathrm{CM}$, and anatomical factors that hamper a complete resection [102,103]. This uncommon subtype has been considered as a distinctive entity since recent genomic studies have supported the notion that UV-light plays a limited role in carcinogenesis $[104,105]$.

The median age of diagnosis is 70 years, and the incidence of MM is higher in women. MM presents a particular metastatic pattern, most often involving the lungs, liver, and bones [106]. Of note, the locoregional nodal involvement is highly common at diagnosis ( $>20 \%)$ [107]. Justified by the overall poor prognosis for even small superficial lesions, the American Joint Committee on Cancer (AJCC) staging system of head and neck MM only adopted T3 and T4 categories, and the four stages of the disease are represented by III, IVA, IVB, and IVC [108].

A complete surgical excision is the primary treatment strategy for localized MM. However, anatomical limitations hamper the possibility of obtaining wide surgical margins. The role of an adjuvant radiotherapy, chemotherapy, or immunotherapy is still a matter of debate [109-111]. 
Systemic therapy is reserved for patients with advanced or recurrent diseases. Although a precise treatment algorithm cannot be defined for this melanoma subtype, treatment approaches often include immunotherapy as an initial strategy for treating these patients.

\subsection{Genetic Landscape and Targeted Therapy Approaches}

During the last years, whole-exome sequencing and whole-genome sequencing technologies allowed for the characterization of the genetic alterations of MM. Particular alterations in the KIT and MAPK pathways should be specially addressed in this rare tumor due to the fact that they have led to the development of target therapies (Figure 1) [112].

\subsubsection{BRAF}

$B R A F$ mutations are present in MM but at a lower frequency (6-12\%) compared to CM [113-115]. In a whole-genome sequencing analysis of $67 \mathrm{MM}$ samples performed by Newell et al., BRAF mutations were most commonly found in the protein tyrosine kinase domain, with V600E, V600K, and V600R being the most common BRAF mutations [116].

On the other hand, non-V600 mutations appear to be present in a higher proportion in MM. In this context, a compiled BRAF mutation analysis of $1339 \mathrm{MM}$ performed by Dumaz et al. showed that $37 \%$ of mutations were placed on another codon different from V600, particularly on D594 (40\%), G469 (24\%), and K601 (16\%) [113].

No randomized clinical trials have been published on the efficacy and safety of targeted therapy for advanced $B R A F$-mutant MM. In a small cohort of 10 patients with metastatic or unresectable BRAF V600E-mutant MM, vemurafenib achieved a 40\% ORR and 90\% disease control rate (DCR) [117]. In light of these results, and considering the remarkable results of the combination of BRAF and MEK inhibition in CM, these drugs should be considered for BRAF-mutant MM. However, despite the initial response, an acquired resistance is expected, and $B R A F$ fusions have been proposed as a resistance mechanism to vemurafenib in this population [118].

\subsubsection{KIT}

The transmembrane tyrosine kinase receptor KIT (v-kit Hardy-Zuckerman 4 feline sarcoma viral oncogene homolog) has a vital role in normal melanocyte growth, differentiation, and migration. Its activation through dimerization regulates multiple downstream signaling pathways, including MAPK and AKT [119].

KIT mutations, most commonly in exon 11 and 13, were found at a rate of 13-18\% in MM [116]. Of note, KIT mutations are especially prevalent in vulvovaginal and anorectal localizations $[105,120]$.

Although Bai et al. have evidenced a worse survival outcome in $66 \mathrm{MM}$ patients with KIT mutations, this finding was not replicated by several other studies [121-124]. Particularly, Hintzsche et al. demonstrated that NF1 and KIT were frequently commutated in 6 out of 19 (32\%) MMs [105].

Considering the efficacy of targeted therapy in KIT-addicted tumors, such as gastrointestinal stromal tumors (GISTs), different prospective studies have evaluated KIT inhibition in melanoma. Although drug activity was commonly observed, the median PFS was around 3 to 4 months in most trials (Table 2). A single-group, open-label, phase 2 trial conducted by Carvajal et al., included 28 imatinib mesylate-treated patients with different subtypes of melanomas and KIT mutations or amplifications. Among 13 patients (46\%) with MM, 23\% achieved a clinical response [88]. A multicenter phase 2 trial conducted by Hodi et al. included 17 patients suffering from metastatic MM harboring mutationally activated or amplified KIT and treated with imatinib mesylate [89]. Interestingly, the ORR among patients with KIT mutations (exon 11,13, and 17) was $64 \%$ (7/11). Contrastingly, imatinib was ineffective in patients that only had KIT amplifications since none of the six patients achieved a clinical response. 
Additional phase 2 trials using nilotinib in KIT-mutant melanoma patients (including MM) exhibited similar responses as seen with imatinib, demonstrating a clinical effect in patients with disease progression imatinib [90-94].

Unlike GISTs, which are characterized by secondary KIT gene mutations, the activation of MAPK and PI3K signaling pathways has been proposed as a possible mechanism of resistance in melanoma [125]. Deylon and collaborators have emphasized the role of STAT3 as a key signaling pathway that is inhibited by good responders to nilotinib [94]. These considerations support the development of clinical trials that evaluate KIT inhibitors along with other agents that target different signaling pathways, such as AKT, mTOR, and STAT3 inhibitors.

\subsubsection{Others}

Other driver mutations are relatively infrequent in MM. The NRAS mutation rate is estimated to be around $8 \%$ [115]. The most frequent locations affected are similar in both CM and MM (Q61, G12, and G13) [113]. NRAS Q61 mutations occur at a lower rate in this population, which may be explained by the association between this particular mutation and UV exposure.

SPRED1 (sprout related, EVH1 domain-containing protein 1), a negative regulator of the MAPK pathway, was proposed as a tumor suppressor in MM models. SPRED1 loss is reported to co-occur in $30 \%$ of MMs with KIT mutations. This association was characterized as a mechanism of resistance to the KIT tyrosine kinase inhibitor dasatinib in preclinical models [126].

The amplification of CDK4 has been found in more than 50\% of cases of MM [115,127]. Treatments with the CDK4/6 inhibitor palbociclib in patient-derived xenografts (PDX) resulted in sustained tumor suppressions for eight weeks [128]. The clinical activity in human patients remains to be elucidated.

Other potential drivers, such as NF1 and GNAQ/GNA11 mutations, have been described in 7-22\% and $9.5 \%$ of patients with MM, respectively. Interestingly, tumors with NF1 alterations have shown to be more resistant to BRAF inhibitors in preclinical models [129-131]. Adequate estimations of the frequency of these mutations cannot be established since multiple studies have reported conflicting results $(0-18 \%)$ [68,131-133].

Finally, mutations in SF3B1 represent 35\% of MMs, most commonly found in anorectal and vulvovaginal localizations $[105,134]$. While clinical implications of this alteration are still not fully elucidated, a meta-analysis including 53 cases with SF3B1 mutations suggested a trend to better the OS [115].

\subsection{Immunotherapy}

Before the immune and targeted therapy era, chemotherapy was the unique option for treating patients suffering from advanced MM. In terms of response to cytotoxic chemotherapy, MM patients exhibited a limited efficacy, similarly to CM. Single-agent or combined regimens showed responses between $15 \%$ and $25 \%$, respectively, but without further improved survival advantages [135-137].

On the other hand, immunotherapy has demonstrated to be a more suitable option in MM than chemotherapy (Table 3). A French multicenter retrospective study compared immunotherapy $(n=151)$ vs. chemotherapy $(n=78)$ as treatment strategies for stage IIIC-IV MM [138]. The authors found a significantly longer median OS for patients in the immunotherapy (anti-PD-1 and anti-CTLA-4) group (15.97 months) as compared to those receiving chemotherapy, mainly dacarbazine (8.82 months).

Concomitantly, a post-hoc analysis of pembrolizumab in 84 patients with advanced mucosal melanoma of KEYNOTE-001, -002, -006 showed an ORR of 22\% (95\% CI 11-35\%) and $15 \%$ (95\% CI $5-32 \%)$ in ipilimumab-naive and ipilimumab-treated patients, respectively. The median PFS in the entire cohort was 2.8 months (95\% CI $2.7 \%$ to $2.8 \%$ ) [139].

Notably, anti-PD-1 seems to be associated with a higher efficacy than anti-CTLA-4 in MM, as it was demonstrated in a cohort of 44 first-line-treated patients with unresectable and/or metastatic MM. Patients achieved an ORR of $35 \%$ and a median PFS of 5 months using pembrolizumab compared to an ORR of $8.2 \%$ and a PFS of 5 months in the ipilimumab group [140]. 
As a result of the impressive efficacy achieved by combining anti-CTLA-4 and anti-PD- 1 in CM, this strategy was analyzed for MM. In a pooled analysis of six trials (phases 1,2, and 3), including 157 patients with MM, D'Angelo et al. compared nivolumab plus ipilimumab, nivolumab alone, and ipilimumab alone [141]. As expected, the combined regimen achieved a better ORR (37.1\%), as compared to nivolumab or ipilimumab monotherapies ( $23.3 \%$ and $8.3 \%$, respectively).

Similarly, combined immunotherapy was evaluated in a subgroup of treatment-naive stage III or IV MM patients treated in CheckMate 067 with nivolumab plus ipilimumab $(n=28)$, nivolumab $(n=23)$, or ipilimumab $(n=28)$. Better outcomes were found for patients receiving the combination (ORR $43 \%$ and PFS 5.8 months), as compared to nivolumab (ORR 30\% and PFS 3 months) and ipilimumab (ORR $7 \%$ and PFS 2.6 months) [142].

Altogether, these findings support the idea that immunotherapy is a valuable treatment option for MM. The combination of anti-PD- 1 and anti-CTLA-4, seems to be a rational strategy for the initial treatment approach, despite having a high incidence of toxicity (55\% of grade 3 to 4 adverse events) [11]. However, the ORR is still lower than CM, which is probably explained by the lower TMB observed in this subtype $[116,143]$.

Remarkably, a more recent strategy may enhance the efficacy of immunotherapy. Angiogenesis modulates the tumor microenvironment of different tumors, including melanomas, and vascular endothelial growth factor (VEGF) was proposed to playing an immunosuppressive role [144,145]. This rationale, already tested in renal cell carcinoma with unprecedented results, was evaluated in two-phase $1 \mathrm{~b}$ and $2 \mathrm{MM}$ trials combining toripalimab, a recombinant humanized PD-1 monoclonal antibody, with the VEGF-receptor inhibitors axitinib or vorolanib. Both studies showed encouraging results (Table 3) [146-149]. The phase $1 \mathrm{~b}$ trial conducted by Sheng et al. investigated the combination of toripalimab and axitinib in 29 treatment-naive patients with metastatic MM [148]. This study showed impressive responses and disease control rates of $48.5 \%$ and $84.8 \%$, respectively. The median PFS and OS were 7.5 and 20.7 months, respectively. Of note, no significant differences were observed according to the PD-L1 expression or TMB. It should be highlighted that although these results need to be validated in larger studies, this combination represents one of the most effective strategies for the treatment of advanced MM to date.

Table 3. Selected studies that assessed immunotherapy in advanced mucosal melanoma.

\begin{tabular}{|c|c|c|c|c|c|c|c|}
\hline Study & Study Type & $N$ & Arms (n) & $\begin{array}{c}\text { ORR } \\
(\%)\end{array}$ & $\begin{array}{c}\text { DCR } \\
(\%)\end{array}$ & $\begin{array}{l}\text { PFS } \\
\text { (mo) }\end{array}$ & $\begin{array}{c}\text { OS } \\
\text { (mo) }\end{array}$ \\
\hline $\begin{array}{l}\text { Postow et al. } \\
2013 \text { [150] }\end{array}$ & $\begin{array}{l}\text { Multicenter, } \\
\text { retrospective }\end{array}$ & 33 & Ipilimumab & 6.7 & 26.7 & NS & 6.4 \\
\hline $\begin{array}{l}\text { Del Vecchio et al. } \\
2014 \text { [151] }\end{array}$ & $\begin{array}{c}\text { Expanded, access } \\
\text { program }\end{array}$ & 71 & Ipilimumab & 11 & 36.2 & 4.3 & 6.4 \\
\hline $\begin{array}{l}\text { Shoushtari et al. } \\
2016 \text { [100] }\end{array}$ & $\begin{array}{l}\text { Multi-institutional, } \\
\text { retrospective }\end{array}$ & 35 & $\begin{array}{l}\text { Nivolumab or } \\
\text { Pembrolizumab }\end{array}$ & 23 & 42.9 & 3.9 & NS \\
\hline $\begin{array}{l}\text { D'Angelo et al. } \\
2017 \text { [141] }\end{array}$ & $\begin{array}{l}\text { Pooled analysis of } \\
\text { phase 1-2-3 studies } b\end{array}$ & 157 & $\begin{array}{c}\text { Nivolumab + } \\
\text { Ipilimumab (86) } \\
\text { Nivolumab (35) } \\
\text { Ipilimumab (36) }\end{array}$ & $\begin{array}{c}37.1 \\
23.3 \\
8.3\end{array}$ & $\begin{array}{l}57.1 \\
45.3 \\
16.7\end{array}$ & $\begin{array}{c}5.9 \\
3 \\
2.7\end{array}$ & NS \\
\hline $\begin{array}{l}\text { Mignard et al. } \\
2018 \text { [138] }\end{array}$ & $\begin{array}{l}\text { Multicenter, } \\
\text { retrospective }\end{array}$ & 151 & $\begin{array}{c}\text { Ipilimumab (76) } \\
\text { Nivolumab or } \\
\text { Pembrolizumab (75) }\end{array}$ & 11.9 & 17.9 & 15.97 & NS \\
\hline Omid et al. 2019 [139] & $\begin{array}{l}\text { Post-hoc analysis of } \\
\text { phase } 1-2-3 \text { studies }\end{array}$ & 84 & Pembrolizumab & 19 & 31 & 2.8 & 11.3 \\
\hline $\begin{array}{l}\text { Postow et al. } \\
2013 \text { [150] }\end{array}$ & $\begin{array}{l}\text { Multicenter, } \\
\text { retrospective }\end{array}$ & 33 & Ipilimumab & 6.7 & 26.7 & NS & 6.4 \\
\hline $\begin{array}{l}\text { Del Vecchio et al. } \\
2014 \text { [151] }\end{array}$ & $\begin{array}{l}\text { Expanded, access } \\
\text { program }\end{array}$ & 71 & Ipilimumab & 11 & 36.2 & 4.3 & 6.4 \\
\hline
\end{tabular}


Table 3. Cont.

\begin{tabular}{|c|c|c|c|c|c|c|c|}
\hline Study & Study Type & $N$ & Arms (n) & $\begin{array}{c}\text { ORR } \\
(\%)\end{array}$ & $\begin{array}{c}\text { DCR } \\
(\%)\end{array}$ & $\begin{array}{l}\text { PFS } \\
\text { (mo) }\end{array}$ & $\begin{array}{c}\text { OS } \\
(\mathrm{mo})\end{array}$ \\
\hline $\begin{array}{c}\text { Shoushtari et al. } \\
2016 \text { [100] }\end{array}$ & $\begin{array}{l}\text { Multi-institutional, } \\
\text { retrospective }\end{array}$ & 35 & $\begin{array}{l}\text { Nivolumab or } \\
\text { Pembrolizumab }\end{array}$ & 23 & 42.9 & 3.9 & NS \\
\hline $\begin{array}{l}\text { D'Angelo et al. } \\
2017 \text { [141] }\end{array}$ & $\begin{array}{l}\text { Pooled analysis of } \\
\text { phase 1-2-3 studies } b\end{array}$ & 157 & $\begin{array}{c}\text { Nivolumab + } \\
\text { Ipilimumab (86) } \\
\text { Nivolumab (35) } \\
\text { Ipilimumab (36) }\end{array}$ & $\begin{array}{c}37.1 \\
23.3 \\
8.3\end{array}$ & $\begin{array}{l}57.1 \\
45.3 \\
16.7\end{array}$ & $\begin{array}{c}5.9 \\
3 \\
2.7\end{array}$ & NS \\
\hline $\begin{array}{l}\text { Mignard et al. } \\
2018 \text { [138] }\end{array}$ & $\begin{array}{l}\text { Multicenter, } \\
\text { retrospective }\end{array}$ & 151 & $\begin{array}{c}\text { Ipilimumab (76) } \\
\text { Nivolumab or } \\
\text { Pembrolizumab (75) }\end{array}$ & 11.9 & 17.9 & 15.97 & NS \\
\hline Omid et al. 2019 [139] & $\begin{array}{l}\text { Post-hoc analysis of } \\
\text { phase 1-2-3 studies }\end{array}$ & 84 & Pembrolizumab & 19 & 31 & 2.8 & 11.3 \\
\hline $\begin{array}{c}\text { Moya-Plana et al. } \\
2019 \text { [140] }\end{array}$ & $\begin{array}{l}\text { Single-center } \\
\text { prospective cohort }\end{array}$ & 44 & $\begin{array}{c}\text { Ipilimumab (24) } \\
\text { Pembrolizumab (20) }\end{array}$ & $\begin{array}{l}8.2 \\
35\end{array}$ & $\begin{array}{l}30 \\
45\end{array}$ & $\begin{array}{l}3 \\
5\end{array}$ & $\begin{array}{c}12 \\
16.2\end{array}$ \\
\hline Si Lu et al. 2019 [152] & Phase $1 b$ & 15 & Pembrolizumab & 13.3 & 20 & NS & NS \\
\hline $\begin{array}{l}\text { Shoushtari et al. } \\
2020 \text { [142] }\end{array}$ & $\begin{array}{c}\text { Subgroup of } \\
\text { CheckMate } 067\end{array}$ & 79 & $\begin{array}{c}\text { Ipilimumab + } \\
\text { Nivolumab (28) } \\
\text { Nivolumab (23) } \\
\text { Ipilimumab (28) }\end{array}$ & $\begin{array}{c}43 \\
30 \\
7\end{array}$ & $\begin{array}{l}57 \\
39 \\
11\end{array}$ & $\begin{array}{l}5.8 \\
3.0 \\
2.6\end{array}$ & $\begin{array}{l}22.7 \\
20.2 \\
12.1\end{array}$ \\
\hline Sheng et al. 2020 [148] & Phase $1 b$ & 29 & $\begin{array}{c}\text { Axitinib }+ \\
\text { Toripalimab }\end{array}$ & 48.5 & 84.8 & 7.5 & 20.7 \\
\hline Si Lu et al. 2020 [149] & Phase 2 & 40 & $\begin{array}{c}\text { Vorolanib + } \\
\text { Toripalimab }\end{array}$ & $15-22.2$ & $55.5-65$ & $5.6-5.7$ & NS \\
\hline
\end{tabular}

Abbreviations: ORR, overall response rate; DCR, disease control rate; PFS, progression-free survival; OS, overall survival; NS, not specified. a Post-hoc analysis of KEYNOTE-001, $-002,-006$ (phase 1, 2, and 3, respectively); ${ }^{\mathrm{b}}$ pooled analysis of phase 1 CA209-003, phase 1 CA209-038, phase 3 CheckMate 066, phase 3 CheckMate 037; phase 3 CheckMate 067, phase 2 CheckMate 069.

\section{Uveal Melanoma}

\subsection{Introduction}

Uveal melanoma (UM) is the most common primary intraocular malignancy in adults, representing $\sim 5 \%$ of all melanomas [2]. Although UM can arise from the pigmented tissue of the iris and ciliary body, more than $90 \%$ of cases emerge from choroids [153]. In contrast to the increasing rate of CM cases observed in the last years, the incidence of UM has remained relatively stable at approximately five per million since the 1970s [154]. This subtype is especially prevalent among white patients with light-colored eyes [155].

Of note, the typical UV mutational signature has not been identified in UM since the cornea, lens, and vitreous act as a barrier between most UV radiation and the choroids [156]. As a consequence, UM shows a remarkably low mutational burden, except for iris melanomas that have been associated with UV-induced DNA damage.

As expected, visual disorders are the most common symptom. However, almost one-third of cases are incidentally detected in a routine ophthalmologic exam [157]. Otherwise, treatment approaches are oriented to preserve eye and vision and include phototherapy, plaque brachytherapy, photon stereotactic radiation therapy, local resection, and enucleation for locally advanced cases. Of note, the metastatic pattern of UM is quite distinctive, characterized by hematogenous dissemination. Liver involvement may occur in approximately $50 \%$ of patients within the first 5 years following diagnosis, or even up to 25 years later [158]. In this scenario, liver-directed therapy is a commonly selected strategy, including surgery, chemoembolization, radioembolization, immunoembolization, and the hepatic arterial infusion of chemotherapy [159]. 


\subsection{Genetic Landscape and Targeted Therapy Approaches}

\subsection{1. $\mathrm{G} \alpha_{\mathrm{q}}$ Signaling}

UMs are not characterized by targetable mutations in BRAF, NRAS, or KIT (Figure 1). Instead, they show a specific somatic mutation profile characterized by oncogenic mutually-exclusive mutations in either GNAQ, GNA11, or sporadically in PLCB4 or CYSLTR2 genes [160]. These mutations lead to G $\alpha_{\mathrm{q}}$ pathway activation with the subsequent stimulation of the MAPK and $\beta$-catenin pathways, as well as the transcriptional co-activator Yes-associated protein 1 (YAP1) through the Trio-Rho/Rac signaling circuit $[161,162]$.

Mutations in GNAQ and GNA11 genes are considered an early development event and are present in $~ 85 \%$ of all UMs $[161,163,164]$. Hotspot GNAQ p.Q209 mutations are found in 45\% of primary UM and $22 \%$ of metastases, while GNA11 p.Q209 mutations are found in 32\% of primary tumors and $57 \%$ of UM metastases [165]. Consequently, it was proposed that GNA11 mutations have a more relevant effect on tumorigenesis since GNA11 Q209 mutations are more frequently observed in the metastasis of UM. Additionally, in mouse models, GNA11 mutations demonstrated to be more tumorigenic than GNAQ mutations [166]. Less frequently, a second mutation was also described at codon p.R183 in both genes $(6 \%)$.

CYSLTR2-mediated signaling promotes the activation of a variety of downstream pathways, including PKC, MAPK, and PI3K signaling. The p.Leu129Gln substitution of CYSLTR2 produces a constitutive activation of endogenous $\mathrm{G} \alpha_{\mathrm{q}}$ and can promote tumorigenesis in vivo [167]. CYSLTR2 somatic mutations were found in around $4 \%$ of UM.

The PLCB4 (phospholipase C $\beta 4$ ) protein plays a crucial role in the intracellular transduction of extracellular signals in the retina and is another downstream effector of $\mathrm{G} \alpha_{\mathrm{q}}$ signaling. A gain-of-function mutation of this gene was reported at a low frequency in UM $(2.5 \%)$ [13,167]. PLCB4 p.D630Y mutations are mutually exclusive with mutations in GNAQ/GNA11.

Concerning the systemic treatment, chemotherapeutic regimens are often recommended in CM, such as dacarbazine, cisplatin, and temozolomide, which were evaluated in patients with UM and poor ORRs $(<10 \%)$ were observed [168].

Notably, other strategies were developed, taking into account that the typical mutations in GNAQ/GNA11 in UM lead to constitutive activation of the MAPK and PI3K/AKT pathways. Thus, logical approaches considered downstream targeted therapies against effector proteins, such as MEK and AKT. Some clinical trials were developed based on this rationale of inhibition of downstream $\mathrm{G} \alpha_{\mathrm{q}}$, (Table 4). In this context, selumetinib (an oral selective MEK1/2 inhibitor) was tested against chemotherapy (temozolomide or dacarbazine) in a phase 2 trial, and in combination with dacarbazine in the phase 3, multicenter, and randomized SUMIT trial. Unfortunately, both studies showed limited clinical activity (ORR 14\% and 3\%, respectively) in advanced UM patients [169,170]. Subsequently, the MEK inhibition trametinib was tested alone or in combination with the AKT inhibitor GSK2141795 in a phase 2 trial, including patients with advanced UM [171]. The combination did not improve the clinical outcomes since patients in the trametinib arm $(n=18)$ achieved an ORR of $5.5 \%$ compared to $4.8 \%$ in the combined arm $(n=21)$. The median PFS was 3.6 months in both groups.

Table 4. Selected studies for therapy of uveal melanoma.

\begin{tabular}{cccccccc}
\hline Study & Study Type & $N$ & Arms (n) & $\begin{array}{c}\text { ORR } \\
\mathbf{( \% )}\end{array}$ & $\begin{array}{c}\text { DCR } \\
(\mathbf{\%})\end{array}$ & $\begin{array}{c}\text { PFS } \\
(\mathbf{m o})\end{array}$ & $\begin{array}{c}\text { OS } \\
(\mathbf{m o})\end{array}$ \\
\hline Luke et al. 2013 [172] & $\begin{array}{c}\text { Multicenter, } \\
\text { retrospective }\end{array}$ & 39 & Ipilimumab & 2.6 & 46 & - & 9.6 \\
\hline Piulats et al. 2014 [173] & Phase 2 & 32 & Ipilimumab & 6.45 & 50 & NS & NS \\
\hline Carvajal et al. 2014 [169] & Phase 2 & 101 & $\begin{array}{c}\text { Selumetinib (50) } \\
\text { Chemotherapy (51) }\end{array}$ & $\begin{array}{c}14 \\
0\end{array}$ & NS & $\begin{array}{c}3.7 \\
1.6\end{array}$ & $\begin{array}{c}11.8 \\
9\end{array}$ \\
\hline Zimmer et al. 2015 [174] & Phase 2 & 53 & Ipilimumab & 0 & 47 & 2.8 & 6.8 \\
\hline
\end{tabular}


Table 4. Cont.

\begin{tabular}{|c|c|c|c|c|c|c|c|}
\hline Study & Study Type & $N$ & Arms (n) & $\begin{array}{c}\text { ORR } \\
(\%)\end{array}$ & $\begin{array}{c}\text { DCR } \\
(\%)\end{array}$ & $\begin{array}{l}\text { PFS } \\
\text { (mo) }\end{array}$ & $\begin{array}{c}\text { OS } \\
(\mathrm{mo})\end{array}$ \\
\hline Joshua et al. 2015 [175] & Phase 2 & 11 & Tremelimumab & 0 & - & 2.9 & 12.8 \\
\hline Shoushtari et al. 2016 [171] & Phase 2 & 39 & $\begin{array}{c}\text { Trametinib (18) } \\
\text { Trametinib + } \\
\text { GSK2141795 }^{\mathrm{a}}(21)\end{array}$ & $\begin{array}{l}5.5 \\
4.8\end{array}$ & NS & $\begin{array}{l}3.6 \\
3.6\end{array}$ & NS \\
\hline Tsai et al. 2016 [176] & $\begin{array}{l}\text { Multicenter, } \\
\text { retrospective }\end{array}$ & 58 & $\begin{array}{c}\text { Pembrolizumab (40) } \\
\text { Nivolumab (16) } \\
\text { Atezolizumab (2) }\end{array}$ & 3 & 10 & 2.7 & 9.5 \\
\hline Piulats et al. 2017 [177] & Phase 2 & 19 & $\begin{array}{l}\text { Nivolumab + } \\
\text { Ipilimumab }\end{array}$ & 15.8 & 63.2 & 4.99 & NR \\
\hline Scheulen et al. 2017 [178] & Phase 2 & 118 & Sorafenib & 1.7 & 66.1 & 5.5 & 14.8 \\
\hline Patel et al. 2017 [179] & Phase 2 & 31 & $\begin{array}{c}\text { Glembatumumab } \\
\text { Vedotin }^{\mathrm{b}}\end{array}$ & 6 & 61 & 3.2 & 11.8 \\
\hline Mignard et al. 2018 [138] & $\begin{array}{l}\text { Multicenter, } \\
\text { Retrospective }\end{array}$ & 100 & $\begin{array}{c}\text { Ipilimumab (63) } \\
\text { Nivolumab or } \\
\text { Pembrolizumab (37) }\end{array}$ & 0 & 32 & - & 13.38 \\
\hline Carvajal et al. 2018 [170] & Phase 3 & 129 & $\begin{array}{c}\text { Selumetinib + } \\
\text { Dacarbazine (97) } \\
\text { Placebo + } \\
\text { Dacarbazine (32) }\end{array}$ & $\begin{array}{l}3 \\
0\end{array}$ & NS & $\begin{array}{l}2.8 \\
1.8\end{array}$ & NS \\
\hline Sato et al. 2018 [180] & Phase $1 / 2$ & 19 & Tebentafusp ${ }^{c}$ & $10.5^{\mathrm{d}}$ & - & - & NR \\
\hline
\end{tabular}

Based on the concept that UMs normally synthesize and secrete vascular endothelial growth factor (VEGF), an additional targeted therapy tested was the oral multi-kinase inhibitor sunitinib [181]. Scheulen et al. developed a phase 2 trial recruiting 118 chemonaive patients with metastatic UM. Unfortunately, only two cases had a partial response (1.7\%), 78 had a stable disease $(66.1 \%)$, and the median PFS was 5.5 months [178].

Although the rationale for all these targeted therapies was innovative, the clinical efficacy is still disappointing.

\subsubsection{Others}

The bi-allelic inactivation of the tumor suppressor gene BAP1 (BRCA1-associated protein 1), accounting for $60 \%$ of UMs, is another critical genetic alteration for UM development. This mutation was related to the metastatic relapse pattern and worse outcomes [182]. BAP1 germline mutations were also linked to a hereditary predisposition to UM [183]. Of note, UM can appear in the context of the BAP1-tumor predisposition syndrome, which is associated with an increased risk for skin cancer (CM and basal cell carcinoma), renal cell carcinoma, and malignant mesothelioma [184].

Together with BAP1 mutations, SF3B1 (splicing factor $3 \mathrm{~b}$ subunit 1), and EIF1AX (eukaryotic translation initiation factor $1 \mathrm{~A}, \mathrm{X}$-linked) formed a second mutually exclusive subgroup in $\mathrm{UM}$. Mutations in SF3B1, most commonly in amino acid 625 (R625), were reported in approximately $10-21 \%$ of UM cases [185-187]. The prognosis of these mutations has conflicting data. Harbour et al. found that patients with SF3B1-mutated UM had a better prognosis compared with the SF3B1 wild-type patients, while Yavuzyigitoglu et al. found that SF3B1 mutations were associated with a significantly worse prognosis and the development of late metastasis $[188,189]$. Otherwise, EIF1AX-mutant UM occurs in $\sim 20 \%$ of UM cases, and a complete understanding of the functional effects of this mutation remains unknown. Notably, EIF1AX-mutant patients showed a better prognosis [186,189].

Furthermore, UM involves additional molecular alterations, such as chromosomal aberration losses of 3,1p, 6q, 8p and 16q, and the amplification of chromosome arms $6 \mathrm{p}$ and $8 \mathrm{q}$. Based on 
the multiplatform analysis of 80 primary UMs, The Cancer Genome Atlas (TCGA) project helped to categorize this rare disease into four main groups with different genetic and immunological profiles, molecular alterations, and prognoses $[190,191]$. In summary, groups A and B harbor EIF1AX and SF3B1 mutations and have a more favorable prognosis, while groups $\mathrm{C}$ and $\mathrm{D}$ are characterized by $B A P 1$ mutations and worse outcomes.

Supported by the role of BAP1 in DNA damage repair, an interesting phase 2 trial would be to explore the efficacy of the PARP inhibitor niraparib in several tumors, including $\mathrm{UM}$, harboring BAP1 and other DNA damage response mutations (NCT03207347) [192].

\subsection{Tumor Immunogenicity and Therapy}

The eye may provide a protective environment for UM development and growth. As a consequence, UM can evade immune surveillance via multiple mechanisms, including a deficiency of co-stimulatory molecules in the presentation of antigens process (CD80 and CD86), and by producing immunosuppressive cytokines, such as IDO1 [190,193-196]. In the same context, PDL-1 has been reported in around $5.1 \%$ of metastatic UMs and $10.6 \%$ of primary samples $[97,197]$. Interestingly, after analyzing 80 primary samples, Basile and colleagues described that PDL-1 was inversely correlated with the tumor thickness, PFS, and OS [198]. Authors have also highlighted the role of HLA-G and certain inmune-checkpoint related genes, such as CD47, CD200, TNFRSF6B, HVEM, and GAL9 as predictive factors for disease-free survival. Furthermore, it was also reported that the leukocyte fraction of tumor immune infiltrates is very low in UM, and only group D is considered inflammated [190,191,194].

Under these circumstances, the role of immunotherapy in this population is still unclear, since the immune checkpoint inhibitors as a monotherapy (anti-CTLA-4 or anti-PD-1/PD-L1) demonstrated a restricted activity in small conducted studies (ORR 0-7\% and median OS $<1$ year (Table 4)). A phase 2 trial developed by The Dermatologic Cooperative Oncology Group (DeCOG), which investigated the efficacy of ipilimumab $3 \mathrm{mg} / \mathrm{kg}$ among 53 patients with treatment-naive metastatic UM. The disease control rate was $47 \%$, and no patients had a complete or partial response. The progression-free survival and OS were 2.8 and 6.8 months, respectively [174]. Similarly, Tsai et al. evaluated pembrolizumab, nivolumab, and atezolizumab as monotherapies in a multicenter retrospective study in 58 metastatic UM. The overall response rate, PFS, and OS were 3\%, 2.7 months, and 9.5 months, respectively [176].

On the other hand, Piulats et al. showed the most promising results to the date with immunotherapy. In a phase 2 single-arm trial, the authors evaluated the combination of ipilimumab and nivolumab in patients with metastatic UM in a first-line setting. Among the 19 cases enrolled, the ORR was $15.8 \%$, and disease stabilization was achieved in $47.4 \%$ of patients. With a median follow-up of 4.6 months, the median PFS was 4.99 months, and the median OS was not reached [177].

Despite the limited results with regard to immune checkpoint inhibition, other novel immune-based approaches were investigated. Encouraging preliminary activities were observed with the novel bispecific protein tebentafusp (IMCgp100) which targets a fragment of the melanocytes lineage-specific antigen gp100 in the context of HLA-A2 (50\% of Caucasians) $[199,200]$. The phase $1 / 2$ study enrolled 19 patients with metastatic UM, and despite having a considerable immune-related toxicity profile, a tumor response was observed in $31.6 \%$ of patients, and the one year PFS and OS rates were $66 \%$ and 74\%, respectively [180]. The pivotal phase II study of IMCgp100 is ongoing (NCT03070392) [201]. Another promising strategy is glembatumumab vedotinb, a monoclonal antibody-drug conjugate against the a transmembrane glycoprotein gpNMB, overexpressed by multiple tumor types, including MM. In the phase 2 trial, including 31 patients with advanced UM, the ORR was $6 \%$ and the DCR was $61 \%$, while the median PFS and OS were 3.2 months and 11.8 months, respectively [179].

Taking into account all of these studies to date, the treatment of advanced UM remains a challenge since the impressive results obtained in CMs could not be translated to this rare subtype.

\section{Unusual or Unknown Primary Site Melanomas}

Unusual primary sites of melanoma (UPSM) are defined as those which do not arise from the skin, the uveal tract of the eye, or various mucosal surfaces. On the other hand, the melanoma of 
an unknown primary (MUP) is defined as the histologically confirmed presence of melanoma in the lymph nodes, viscera, or distant skin subcutaneous tissue, without a history of primary melanoma. An adequate characterization of UPSMs and MUPs is subject to controversy, considering that some cases of MUPs cannot be sharply distinguished from UPSM. Our approach is to consider UPSMs as unique entities, represented by a single lesion that arises in uncommon localizations. These types of entities, such as dermal melanomas and melanomas arising in brain and meninges, are usually associated with clinical and biological characteristics that support this distinction. Furthermore, $\mathrm{CM}$ with spontaneous remission is a potential differential diagnosis that has to be taken into consideration. In this way, some classic studies have excluded MUP characterizations-cases where patients reported a history of skin lesion resection or eye enucleation [202].

According to the different case series and reviews published, the incidence of MUPs is between $2 \%$ and $5 \%$ of all melanomas. MUPs are classified into three categories, including subcutaneous, nodal, and visceral diseases [1]. Nodal is usually considered the most common subtype ranging between $0.7 \%$ and $8.8 \%$, being axillar lymph nodes among the most frequent initial localizations [203]. Nevertheless, it needs to be highlighted that the definition of MUP varies among series, and a large Dutch retrospective study, which gathered information from 2028 patients with MUP, has described that a visceral involvement can be evidenced in around $51 \%$ of included patients [203].

A systematic review and meta-analysis provided evidence that MUP is associated with a better prognosis than stage III (HR 0.83, 95\% CI 0.73-0.96) and stage IV CM (HR 0.85, 95\% CI 0.75-0.96). The role of a spontaneous immune response in the primary lesion may be defined as an interesting explanation for this finding [204]. Interestingly, the genetic characterization of this entity showed a higher rate of mutations in BRAF and NRAS genes, representing $53 \%$ and $14 \%$ of analyzed samples respectively, as well as more mutations in the TERT promoter [205].

Recent studies have intriguingly suggested that patients with MUP may benefit from immunotherapy. Gambicher et al., described that seven of nine patients $(77.8 \%)$ diagnosed with MUP achieved disease control after immunotherapy initiation [206]. In the Dutch series, Verver and colleagues compared the outcomes of MUP patients that were treated with novel therapies, such as checkpoint inhibitors or targeted therapies, with the other group of patients included in the registry from 2011 to 2016 [203]. The authors reported that the median OS was 11 and 4 months, respectively. Notably, the included patients that had undergone targeted therapies and immune checkpoint inhibitors in the first-line treatment experienced a median OS of 18 months. These results suggest that the definition of treatment in MUP should follow the current treatment strategies for CM.

Nowadays, MUP and UPSM are a diagnosis of exclusion, and efforts should be oriented to perform sufficient procedures to exclude the potential primary localizations. Initial strategies include clinical examination, imaging diagnosis, otorhinolaryngological, ophthalmological, gynecological, and urological exams when appropriate. Anorectal, subungual, and mucosal inspections are necessary examinations to a complete assessment, which also may include lower and upper gastrointestinal, bronchial, and nasopharyngeal endoscopies. Positron emission tomography (PET), with 18F-fluoro-2-deoxy-d-glucose (FDG), is superior to morphologic imaging to detect systemic disease and has replaced MRI, CT, and exhaustive endoscopies as the first steps of examination. A meta-analysis that included 2150 patients with advanced-stage melanomas (III and IV) found that FDG-PET had a sensitivity of $86 \%$ and $87 \%$ specificity for detecting metastases [207].

The identification of radiopharmaceutical tracers is a priority to better characterize rare tumors. Emerging models include the combination of monitoring fatty acid uptake and lipoprotein lipase with desorption electrospray ionization-mass spectrometry (DESI-mS), dual-isotope theranostics with fluorine-18 and DOTA, ${ }^{18}$ F-labeled benzamide, gold nanoparticles conjugated with the $\alpha$-melanocyte-stimulating hormone peptide radiolabeled with ${ }^{64} \mathrm{Cu}$, and iodinated melanin-targeting compounds [208]. The activity of these methods for tracing melanoma in human patients is yet to be confirmed. 


\subsection{Brain and Meninges}

Primary intracranial and meningeal melanomas (PIMMs) are rare tumors probably derived from neural crest cells. PIMM represents $1 \%$ of all melanomas and $0.05 \%$ of primary brain tumors. The main areas involved are the pons, cerebellum, cerebral peduncles, interpeduncular fossa, base brain, and spinal cord (cervical region) [209].

The World Health Organization (WHO) classification divides the melanocytic lesions of the central nervous system into three types: diffuse melanosis, meningeal melanocytoma (benign course), and melanoma [210]. Considering the latter, two forms of PIMM should be highlighted: solid tumors and diffuse meningeal melanomatosis [211].

A diagnostic workup usually involves an MRI scan and biopsy or cytology of suspicious lesions. MRI characteristic lesions usually exhibit hyper-intensity on T1 and iso- to hypo-intensity on T2. Immunohistochemistry is crucial and recommended in pathologic analyses. PIMMs are commonly positive for HMB-45, melan A, and S-100 [212]. This technique is especially useful for detecting amelanotic meningeal melanoma (AMM), representing 10\% of PIMMs [213].

The median OS of patients with a PIMM diagnosis is around one year. Of note, a better prognosis was reported in patients with primary spinal cord lesions [214].

PIMM is associated with a low immunogenicity. These tumors have similar mutations to UM, including a high prevalence of GNAQ/GNA11 mutations, and infrequent BRAF mutations. Kusters et al. reported the first whole-exome sequencing analysis of a primary leptomeningeal melanoma, showing a total of 27 somatic mutations, which accounts for a relatively low number in comparison to other melanoma subtypes [215].

Although there is no standard treatment for primary PIMMs, surgery is probably the main local control approach, followed by stereotaxic or whole-brain radiotherapy as an adjuvant treatment in selected cases.

Results of modern therapies for PIMMs have been scarcely reported. Fujimori et al. described one of the first case reports of a patient with BRAF-mutant PIMM treated with vemurafenib and nivolumab, with no clinical benefit [216]. El Habnouni et al. reported a case of an 86-year-old female with a PIMM that harbored a BAP1-inactivating mutation and undetectable PDL-1, with treatment failure after 16 weeks of pembrolizumab [217]. The primary resistance to modern therapies could be explained by the indemnity of the blood-brain barrier in patients with PIMM.

\subsection{Primary Dermal Melanoma}

Primary or solitary dermal melanomas (PDM) are typically described as well-circumscribed nodules localized in the dermis or subcutaneous tissue, without any evidence of involvement or signs of tumor regression in the epidermis.

Cassarino and colleagues' analysis of 13 samples of PDM supports the existence of particular immunohistochemical characteristics that may distinguish between primary nodular melanoma, metastatic cutaneous melanoma, and PDM [218]. According to the authors' findings, the latter is associated with a low expression of cyclin D1, Ki-67, D2-40 and p53, which can explain the less aggressive behavior of this tumor model. Teow and collaborators did not find evidence of BRAF mutations in a series of 12 cases of PDM [219].

A lymph node compromise is rarely observed in PDM. In a series reported by Harris et al., none of the 32 patients that underwent a sentinel lymph node biopsy had positive nodes [220]. The five-year OS in 62 patients was $87.1 \%$, supporting the already reported favorable prognosis of patients with this particular subtype [221]. Consequently, wide excisions, with 2-cm margins are usually the selected treatment approach. Due to its infrequency, a sentinel node biopsy is not uniformly conducted in this population [219].

\subsection{Esophageal Melanoma}

The occurrence of melanoma in the esophagus in classically explained by the presence of melanocytes in up to $2.5-8 \%$ of the tissue, especially in the middle and lower third of the organ [222]. 
Schizas and colleagues have recently reported an exhaustive systematic review that collected data from 93 patients with esophageal melanoma reported in 59 studies [223]. The authors reported an increased incidence of male patients (2:1) having tumors most frequently localized at the lower (48.4\%) and middle esophagus (46.2\%). Multifocality and necrosis were observed in approximately one in five cases.

Surgical treatments should be carefully planned, and usually consist of a total or subtotal esophagectomy or a gastrectomy in the cases where the gastroesophageal junction is involved. Mainly, lymph node involvement can be found in up to $66 \%$ of patients with esophageal melanoma [224]. An extended lymphadenectomy is often performed as part of a surgical treatment in this setting, usually including mediastinal, esophageal, and celiac axis nodes. Nevertheless, Schizas and colleagues did not find a statistically significant association of lymphadenectomy and OS [223]. The prognosis of primary esophageal melanoma is poor. Gao and colleagues have reported in a series of 17 patients a 5-year OS of $10 \%$, and a median OS of only 18.1 months [225].

There are only a few reports regarding the use of checkpoint inhibitors in advanced settings. Rochefort and colleagues published a 75-year-old patient who received treatment with nivolumab, achieving disease stability for approximately six months before progression [225]. In their series, Hashimoto et al. included a case of a patient that only received two cycles of nivolumab before clinical deterioration. Due to its rarity, a standardized treatment for this disease has not been established [226].

\subsection{Primary Malignant Melanoma of the Breast and other UPSM}

Primary malignant melanomas of the breast (PMMB) are exceedingly rare entities [227]. There are differential diagnoses, such as poorly differentiated breast carcinomas, hystiocytic sarcomas, and clear cell sarcomas.

In this particular setting, the distinction between a PMMB and a MUP is particularly challenging. In fact, a classical series of the MD Anderson Cancer Center documented that melanoma is the most frequent origin of metastases in the breast, accounting for 38.5\% of the 169 evaluated cases [228]. While the characterization of PMMB has been limited to a few literature reports, Rassouli and colleagues explained that PMMB might arise from ectopic melanocytes incorporated in the breast epithelium, or as the result of metaplastic changes in breast duct cells [229]. In their literature review, only two of the evaluated cases presented axillary lymph node metastases, which could be interpreted as a distinctive metastatic pattern of PMMB.

Standard treatments for this localization cannot be defined, and a common approach includes surgical resection and a sentinel lymph node biopsy. An adjuvant radiotherapy can be considered in selected scenarios. Notably, the case reported by Rassouli et al., and the two patients documented by Koh and colleagues, were associated with BRAF V600E mutations [230].

The characterization of other UPSM is challenging. Uncommon locations for UPSMs, such as lung, esophagus, pancreas, bone, heart, spleen, and lymph nodes, have been reported in the literature as case reports or series, hampering an adequate characterization [231]. The surgical treatment represents a reasonable strategy for isolated UPSMs.

Given the limited information in the literature, the treatments for patients with UPMS are often defined on a case by case basis. Nevertheless, anatomic criteria should also be considered in the definition and characterization of rare melanomas, and more efforts are needed to understand the pathogenesis and biological particularities of these infrequent subtypes.

\section{Conclusions}

Rare diseases are often defined as entities with a low incidence. Our approach was to determine clinical-biological characteristics and treatment perspectives regarding uncommon melanoma subtypes with distinctive anatomical, histological, or molecular features.

In recent years, impressive progress has been achieved for $\mathrm{CM}$, particularly combining surgery and high-efficacy new drugs. Even in distinctive subgroups not prospectively evaluated in phase 
3 randomized clinical trials, such as CM with NRAS mutations, treatment strategies typically include surgical approaches for localized melanoma and immune checkpoint inhibitors in advanced scenarios.

The advent of targeted therapies highlights the role of molecular characterization in melanomas. BRAF V600 mutations are identified mostly in CM but should also be considered in the treatment algorithm of MM and even in atypical tumor localizations, such as PMMB. Emerging agents, directed to other possible actionable mutations, support the necessity of the further comprehensive molecular profiling of the different melanoma models addressed in this review. Interestingly, the identification of ALK isoforms, and ROS1 or NTRK fusions, may bring new treatment options for CM patients.

The identification of specific mutation signatures, such as UV-induced signatures, may also contribute to treatment decisions. This mutational pattern may explain the high response rates reported in patients with desmoplastic melanoma after immune checkpoint inhibitors. Notably, a substantial benefit with immunotherapy was also documented in patients with angiosarcoma of the head, neck, face, and scalp when UV-induced mutations were noticed [232].

Interestingly, recent clinical trials evaluating MM have shown stimulating results using immunotherapy, especially in combination, and with tyrosine kinase inhibitors. However, clinical benefits are still limited when compared to CM. Similarly, both therapies have shown a restricted efficacy for other melanomas subtypes, such as UM.

Our review also included the analysis of UPSM, considering that these extremely infrequent entities may harbor distinctive clinical and biological characteristics, including specific mutations, spreading routes, and prognoses. The current literature supports this categorization for some atypical localizations, such as the case of the high prevalence of GNAQ/GNA11 mutations in PIMMs, or the favorable prognosis and infrequent lymph node involvement evidenced in patients with PDMs.

Other entities initially localized in atypical organs, such as the breast, lung, kidney, or liver, represent a truly diagnostic challenge, and current evidence does not allow a clear separation between a UPSM and a MUP. In these cases, physical exams and further workups to identify a more typical primary site is the first essential step.

Possibly, in this scenario, genomic tumor profiling represents an opportunity to improve diagnoses and clinical management. In this context, the NOMINATOR study documented the results of the next-generation sequencing profiling of 121 patients with rare cancers [233]. An actionable finding was evidenced in $51 \%$ of the included cases, and notably, four patients with an original diagnosis of soft tissue tumors were genotypically recategorized as NF1 and high TMB melanomas with UV-induced mutations.

Consequently, more efforts should be made to characterize the molecular patterns and to define treatment perspectives for patients with rare melanomas, including primaries with uncommon localizations and MUP. Importantly, a multidisciplinary approach remains crucial to address and guide patient care in patients with these rare conditions.

Author Contributions: All authors have contributed substantially to the elaboration of the manuscript. All authors have read and agreed to the published version of the manuscript.

Funding: This research received no external funding.

Acknowledgments: We thank the Sarcoma European Latin American Network (SELNET) for the publication support.

Conflicts of Interest: The authors declare no conflict of interest.

\section{References}

1. Thoelke, A.; Willrodt, S.; Hauschild, A.; Schadendorf, D. Primary extracutaneous malignant melanoma: A comprehensive review with emphasis on treatment. Onkologie 2004, 27, 492-499. [CrossRef] [PubMed]

2. Chang, A.E.; Karnell, L.H.; Menck, H.R. The National Cancer Data Base report on cutaneous and noncutaneous melanoma: A summary of 84,836 cases from the past decade. The American College of Surgeons Commission on Cancer and the American Cancer Society. Cancer 1998, 83, 1664-1678. [CrossRef] 
3. McLaughlin, C.C.; Wu, X.-C.; Jemal, A.; Martin, H.J.; Roche, L.M.; Chen, V.W. Incidence of noncutaneous melanomas in the U.S. Cancer 2005, 103, 1000-1007. [CrossRef] [PubMed]

4. Pires da Silva, I.; Wang, K.Y.X.; Wilmott, J.S.; Holst, J.; Carlino, M.S.; Park, J.J.; Quek, C.; Wongchenko, M.; Yan, Y.; Mann, G.; et al. Distinct Molecular Profiles and Immunotherapy Treatment Outcomes of V600E and V600K BRAF-Mutant Melanoma. Clin. Cancer Res. 2019, 25, 1272-1279. [CrossRef]

5. Long, G.V.; Menzies, A.M.; Nagrial, A.M.; Haydu, L.E.; Hamilton, A.L.; Mann, G.J.; Hughes, T.M.; Thompson, J.F.; Scolyer, R.A.; Kefford, R.F. Prognostic and clinicopathologic associations of oncogenic BRAF in metastatic melanoma. J. Clin. Oncol. 2011, 29, 1239-1246. [CrossRef] [PubMed]

6. Davies, H.; Bignell, G.R.; Cox, C.; Stephens, P.; Edkins, S.; Clegg, S.; Teague, J.; Woffendin, H.; Garnett, M.J.; Bottomley, W.; et al. Mutations of the BRAF gene in human cancer. Nature 2002, 417, 949-954. [CrossRef]

7. Melis, C.; Rogiers, A.; Bechter, O.; van den Oord, J.J. Molecular genetic and immunotherapeutic targets in metastatic melanoma. Virchows Arch. Int. J. Pathol. 2017, 471, 281-293. [CrossRef]

8. Long, G.V.; Hauschild, A.; Santinami, M.; Atkinson, V.; Mandalà, M.; Chiarion-Sileni, V.; Larkin, J.; Nyakas, M.; Dutriaux, C.; Haydon, A.; et al. Adjuvant Dabrafenib plus Trametinib in Stage III BRAF-Mutated Melanoma. N. Engl. J. Med. 2017, 377, 1813-1823. [CrossRef]

9. Robert, C.; Grob, J.J.; Stroyakovskiy, D.; Karaszewska, B.; Hauschild, A.; Levchenko, E.; Chiarion Sileni, V.; Schachter, J.; Garbe, C.; Bondarenko, I.; et al. Five-Year Outcomes with Dabrafenib plus Trametinib in Metastatic Melanoma. N. Engl. J. Med. 2019, 381, 626-636. [CrossRef]

10. Eggermont, A.M.M.; Chiarion-Sileni, V.; Grob, J.-J.; Dummer, R.; Wolchok, J.D.; Schmidt, H.; Hamid, O.; Robert, C.; Ascierto, P.A.; Richards, J.M.; et al. Adjuvant ipilimumab versus placebo after complete resection of high-risk stage III melanoma (EORTC 18071): A randomised, double-blind, phase 3 trial. Lancet Oncol. 2015, 16, 522-530. [CrossRef]

11. Larkin, J.; Chiarion-Sileni, V.; Gonzalez, R.; Grob, J.J.; Cowey, C.L.; Lao, C.D.; Schadendorf, D.; Dummer, R.; Smylie, M.; Rutkowski, P.; et al. Combined Nivolumab and Ipilimumab or Monotherapy in Untreated Melanoma. N. Engl. J. Med. 2015, 373, 23-34. [CrossRef] [PubMed]

12. Schachter, J.; Ribas, A.; Long, G.V.; Arance, A.; Grob, J.-J.; Mortier, L.; Daud, A.; Carlino, M.S.; McNeil, C.; Lotem, M.; et al. Pembrolizumab versus ipilimumab for advanced melanoma: Final overall survival results of a multicentre, randomised, open-label phase 3 study (KEYNOTE-006). Lancet Lond. Engl. 2017, 390, 1853-1862. [CrossRef]

13. Cancer Genome Atlas Network Genomic Classification of Cutaneous Melanoma. Cell 2015, 161, 1681-1696. [CrossRef]

14. Jakob, J.A.; Bassett, R.L.; Ng, C.S.; Curry, J.L.; Joseph, R.W.; Alvarado, G.C.; Rohlfs, M.L.; Richard, J.; Gershenwald, J.E.; Kim, K.B.; et al. NRAS mutation status is an independent prognostic factor in metastatic melanoma. Cancer 2012, 118, 4014-4023. [CrossRef] [PubMed]

15. Gutiérrez-Castañeda, L.D.; Nova, J.A.; Tovar-Parra, J.D. Frequency of mutations in BRAF, NRAS, and KIT in different populations and histological subtypes of melanoma: A systemic review. Melanoma Res. 2020, 30, 62-70. [CrossRef] [PubMed]

16. Savoia, P.; Fava, P.; Casoni, F.; Cremona, O. Targeting the ERK Signaling Pathway in Melanoma. Int. J. Mol. Sci. 2019, 20, 1483. [CrossRef]

17. Devitt, B.; Liu, W.; Salemi, R.; Wolfe, R.; Kelly, J.; Tzen, C.-Y.; Dobrovic, A.; McArthur, G. Clinical outcome and pathological features associated with NRAS mutation in cutaneous melanoma. Pigment Cell Melanoma Res. 2011, 24, 666-672. [CrossRef] [PubMed]

18. Dummer, R.; Schadendorf, D.; Ascierto, P.A.; Arance, A.; Dutriaux, C.; Di Giacomo, A.M.; Rutkowski, P.; Del Vecchio, M.; Gutzmer, R.; Mandala, M.; et al. Binimetinib versus dacarbazine in patients with advanced NRAS-mutant melanoma (NEMO): A multicentre, open-label, randomised, phase 3 trial. Lancet Oncol. 2017, 18, 435-445. [CrossRef]

19. Lebbe, C.; Dutriaux, C.; Lesimple, T.; Kruit, W.; Kerger, J.; Thomas, L.; Guillot, B.; de Braud, F.; Garbe, C.; Grob, J.J.; et al. Pimasertib (PIM) versus dacarbazine (DTIC) in patients (pts) with cutaneous NRAS melanoma: A controlled, open-label phase II trial with crossover. Ann. Oncol. 2016, 27, vi389. [CrossRef]

20. Ascierto, P.A.; Schadendorf, D.; Berking, C.; Agarwala, S.S.; van Herpen, C.M.; Queirolo, P.; Blank, C.U.; Hauschild, A.; Beck, J.T.; St-Pierre, A.; et al. MEK162 for patients with advanced melanoma harbouring NRAS or Val600 BRAF mutations: A non-randomised, open-label phase 2 study. Lancet Oncol. 2013, 14, 249-256. [CrossRef] 
21. Kirkwood, J.M.; Bastholt, L.; Robert, C.; Sosman, J.; Larkin, J.; Hersey, P.; Middleton, M.; Cantarini, M.; Zazulina, V.; Kemsley, K.; et al. Phase II, open-label, randomized trial of the MEK1/2 inhibitor selumetinib as monotherapy versus temozolomide in patients with advanced melanoma. Clin. Cancer Res. 2012, 18, 555-567. [CrossRef] [PubMed]

22. Kim, T.W.; Lee, J.; Shin, S.J.; Kim, J.-S.; Kim, Y.J.; Han, H.S.; Lee, S.J.; Lim, H.-S.; Hong, Y.; Noh, Y.S.; et al. Belvarafenib, a novel pan-RAF inhibitor, in solid tumor patients harboring BRAF, KRAS, or NRAS mutations: Phase I study. J. Clin. Oncol. 2019, 37, 3000. [CrossRef]

23. Schuler, M.H.; Ascierto, P.A.; De Vos, F.Y.F.L.; Postow, M.A.; Van Herpen, C.M.L.; Carlino, M.S.; Sosman, J.A.; Berking, C.; Long, G.V.; Weise, A.; et al. Phase 1b/2 trial of ribociclib+binimetinib in metastatic NRAS-mutant melanoma: Safety, efficacy, and recommended phase 2 dose (RP2D). J. Clin. Oncol. 2017, 35, 9519. [CrossRef]

24. Algazi, A.P.; Esteve-Puig, R.; Nosrati, A.; Hinds, B.; Hobbs-Muthukumar, A.; Nandoskar, P.; Ortiz-Urda, S.; Chapman, P.B.; Daud, A. Dual MEK/AKT inhibition with trametinib and GSK2141795 does not yield clinical benefit in metastatic NRAS-mutant and wild-type melanoma. Pigment Cell Melanoma Res. 2018, 31, 110-114. [CrossRef]

25. Sullivan, R.J.; Infante, J.R.; Janku, F.; Wong, D.J.L.; Sosman, J.A.; Keedy, V.; Patel, M.R.; Shapiro, G.I.; Mier, J.W.; Tolcher, A.W.; et al. First-in-Class ERK1/2 Inhibitor Ulixertinib (BVD-523) in Patients with MAPK Mutant Advanced Solid Tumors: Results of a Phase I Dose-Escalation and Expansion Study. Cancer Discov. 2018, 8, 184-195. [CrossRef]

26. Falchook, G.S.; Lewis, K.D.; Infante, J.R.; Gordon, M.S.; Vogelzang, N.J.; DeMarini, D.J.; Sun, P.; Moy, C.; Szabo, S.A.; Roadcap, L.T.; et al. Activity of the oral MEK inhibitor trametinib in patients with advanced melanoma: A phase 1 dose-escalation trial. Lancet Oncol. 2012, 13, 782-789. [CrossRef]

27. Kirchberger, M.C.; Ugurel, S.; Mangana, J.; Heppt, M.V.; Eigentler, T.K.; Berking, C.; Schadendorf, D.; Schuler, G.; Dummer, R.; Heinzerling, L. MEK inhibition may increase survival of NRAS-mutated melanoma patients treated with checkpoint blockade: Results of a retrospective multicentre analysis of 364 patients. Eur. J. Cancer 2018, 98, 10-16. [CrossRef]

28. Johnson, D.B.; Lovly, C.M.; Flavin, M.; Panageas, K.S.; Ayers, G.D.; Zhao, Z.; Iams, W.T.; Colgan, M.; DeNoble, S.; Terry, C.R.; et al. Impact of NRAS mutations for patients with advanced melanoma treated with immune therapies. Cancer Immunol. Res. 2015, 3, 288-295. [CrossRef]

29. A Phase Ia/Ib Clinical Study to Evaluate the Safety, Pharmacokinetics (PK) and Preliminary Anti-Tumor Activity of FCN-159 in Patients with Advanced Melanoma Harboring NRAS-Aberrant (Ia) and NRAS-Mutant (Ib). Available online: https://clinicaltrials.gov/ct2/show/NCT03932253 (accessed on 25 June 2020).

30. ClinicalTrials.gov, MEK and Autophagy Inhibition in Metastatic/Locally Advanced, Unresectable Neuroblastoma RAS (NRAS) Melanoma (CHLOROTRAMMEL). Available online: https://clinicaltrials. gov/ct2/show/NCT03979651 (accessed on 25 June 2020).

31. ClinicalTrials.gov, Nivolumab and Trametinib with or without Dabrafenib in Treating Patients with BRAF Mutated or Wild Type Metastatic Stage III-IV Melanoma That Cannot Be Removed by Surgery. Available online: https://clinicaltrials.gov/ct2/show/NCT02910700 (accessed on 25 June 2020).

32. Shahabi, V.; Whitney, G.; Hamid, O.; Schmidt, H.; Chasalow, S.D.; Alaparthy, S.; Jackson, J.R. Assessment of association between BRAF-V600E mutation status in melanomas and clinical response to ipilimumab. Cancer Immunol. Immunother. 2012, 61, 733-737. [CrossRef]

33. Dinter, L.; Karitzky, P.; Kaeubler, T.; Niessner, H.; Wanke, I.; Beissert, S.; Meier, F.; Westphal, D. BRAF/MEK inhibitors induce potent ER stress-Enforced apoptosis in BRAFwt/NRASmut melanoma cells—Insights into mode of action and resistance mechanisms. In Proceedings of the 16th International Society for Melanoma Research Congress, Salt Lake City, UT, USA, 20-21 November 2019; p. 249.

34. Wiesner, T.; Kiuru, M.; Scott, S.N.; Arcila, M.; Halpern, A.C.; Hollmann, T.; Berger, M.F.; Busam, K.J. NF1 Mutations Are Common in Desmoplastic Melanoma. Am. J. Surg. Pathol. 2015, 39, 1357-1362. [CrossRef]

35. Kiuru, M.; Busam, K.J. The NF1 gene in tumor syndromes and melanoma. Lab. Investig. 2017, 97, $146-157$. [CrossRef] [PubMed]

36. Garman, B.; Anastopoulos, I.N.; Krepler, C.; Brafford, P.; Sproesser, K.; Jiang, Y.; Wubbenhorst, B.; Amaravadi, R.; Bennett, J.; Beqiri, M.; et al. Genetic and Genomic Characterization of 462 Melanoma Patient-Derived Xenografts, Tumor Biopsies, and Cell Lines. Cell Rep. 2017, 21, 1936-1952. [CrossRef] [PubMed] 
37. Eroglu, Z.; Zaretsky, J.M.; Hu-Lieskovan, S.; Kim, D.W.; Algazi, A.; Johnson, D.B.; Liniker, E.; Kong, B.; Munhoz, R.; Rapisuwon, S.; et al. High response rate to PD-1 blockade in desmoplastic melanomas. Nature 2018, 553, 347-350. [CrossRef] [PubMed]

38. Long, G.V.; Stroyakovskiy, D.; Gogas, H.; Levchenko, E.; de Braud, F.; Larkin, J.; Garbe, C.; Jouary, T.; Hauschild, A.; Grob, J.J.; et al. Combined BRAF and MEK inhibition versus BRAF inhibition alone in melanoma. N. Engl. J. Med. 2014, 371, 1877-1888. [CrossRef] [PubMed]

39. Menzies, A.M.; Haydu, L.E.; Visintin, L.; Carlino, M.S.; Howle, J.R.; Thompson, J.F.; Kefford, R.F.; Scolyer, R.A.; Long, G.V. Distinguishing clinicopathologic features of patients with V600E and V600K BRAF-mutant metastatic melanoma. Clin. Cancer Res. 2012, 18, 3242-3249. [CrossRef] [PubMed]

40. Malkhasyan, K.A.; Rooney, S.L.; Snow, A.N.; Swick, B.L.; Milhem, M.M.; Zakharia, Y. The clinical characteristics of melanoma with BRAF V600R mutation: A case series study. Melanoma Res. 2020, 30, 107-112. [CrossRef]

41. Klein, O.; Clements, A.; Menzies, A.M.; O’Toole, S.; Kefford, R.F.; Long, G.V. BRAF inhibitor activity in V600R metastatic melanoma. Eur. J. Cancer 2013, 49, 1073-1079. [CrossRef]

42. Menzer, C.; Menzies, A.M.; Carlino, M.S.; Reijers, I.; Groen, E.J.; Eigentler, T.; de Groot, J.W.B.; van der Veldt, A.A.M.; Johnson, D.B.; Meiss, F.; et al. Targeted Therapy in Advanced Melanoma With Rare BRAF Mutations. J. Clin. Oncol. 2019, 37, 3142-3151. [CrossRef]

43. Lokhandwala, P.M.; Tseng, L.-H.; Rodriguez, E.; Zheng, G.; Pallavajjalla, A.; Gocke, C.D.; Eshleman, J.R.; Lin, M.-T. Clinical mutational profiling and categorization of BRAF mutations in melanomas using next generation sequencing. BMC Cancer 2019, 19, 665. [CrossRef]

44. Coit, D.G.; Thompson, J.A.; Algazi, A.; Andtbacka, R.; Bichakjian, C.K.; Carson, W.E.; Daniels, G.A.; DiMaio, D.; Fields, R.C.; Fleming, M.D. NCCN guidelines insights: Melanoma, version 3.2020. J. Natl. Compr. Cancer Netw. 2020, 14, 945-958.

45. Busam, K.J.; Vilain, R.E.; Lum, T.; Busam, J.A.; Hollmann, T.J.; Saw, R.P.M.; Coit, D.C.; Scolyer, R.A.; Wiesner, T. Primary and Metastatic Cutaneous Melanomas Express ALK Through Alternative Transcriptional Initiation. Am. J. Surg. Pathol. 2016, 40, 786-795. [CrossRef] [PubMed]

46. Lezcano, C.; Shoushtari, A.N.; Ariyan, C.; Hollmann, T.J.; Busam, K.J. Primary and Metastatic Melanoma With NTRK Fusions. Am. J. Surg. Pathol. 2018, 42, 1052-1058. [CrossRef] [PubMed]

47. Niu, H.-T.; Zhou, Q.-M.; Wang, F.; Shao, Q.; Guan, Y.-X.; Wen, X.-Z.; Chen, L.-Z.; Feng, Q.-S.; Li, W.; Zeng, Y.-X.; et al. Identification of anaplastic lymphoma kinase break points and oncogenic mutation profiles in acral/mucosal melanomas. Pigment Cell Melanoma Res. 2013, 26, 646-653. [CrossRef] [PubMed]

48. Turner, J.; Couts, K.; Sheren, J.; Saichaemchan, S.; Ariyawutyakorn, W.; Avolio, I.; Cabral, E.; Glogowska, M.; Amato, C.; Robinson, S.; et al. Kinase gene fusions in defined subsets of melanoma. Pigment Cell Melanoma Res. 2017, 30, 53-62. [CrossRef] [PubMed]

49. Handolias, D.; Salemi, R.; Murray, W.; Tan, A.; Liu, W.; Viros, A.; Dobrovic, A.; Kelly, J.; McArthur, G.A. Mutations in KIT occur at low frequency in melanomas arising from anatomical sites associated with chronic and intermittent sun exposure. Pigment Cell Melanoma Res. 2010, 23, 210-215. [CrossRef]

50. Tzen, C.-Y.; Wu, Y.-H.; Tzen, C.-Y. Characterization of KIT mutation in melanoma. Dermatol. Sin. 2014, 32, 7-12. [CrossRef]

51. Pizzichetta, M.A.; Talamini, R.; Stanganelli, I.; Puddu, P.; Bono, R.; Argenziano, G.; Veronesi, A.; Trevisan, G.; Rabinovitz, H.; Soyer, H.P. Amelanotic/hypomelanotic melanoma: Clinical and dermoscopic features. Br. J. Dermatol. 2004, 150, 1117-1124. [CrossRef]

52. Thomas, N.E.; Kricker, A.; Waxweiler, W.T.; Dillon, P.M.; Busman, K.J.; From, L.; Groben, P.A.; Armstrong, B.K.; Anton-Culver, H.; Gruber, S.B.; et al. Comparison of clinicopathologic features and survival of histopathologically amelanotic and pigmented melanomas: A population-based study. JAMA Dermatol. 2014, 150, 1306-1314. [CrossRef]

53. Cheung, W.L.; Patel, R.R.; Leonard, A.; Firoz, B.; Meehan, S.A. Amelanotic melanoma: A detailed morphologic analysis with clinicopathologic correlation of 75 cases. J. Cutan. Pathol. 2012, 39, 33-39. [CrossRef]

54. Zalaudek, I.; Meiklejohn, W.; Argenziano, G.; Thurber, A.E.; Sturm, R.A. “White" nevi and "red" melanomas: Association with the RHC phenotype of the MC1R gene. J. Investig. Dermatol. 2009, 129, 1305-1307. [CrossRef] 
55. Ghiorzo, P.; Pastorino, L.; Pizzichetta, M.A.; Bono, R.; Queirolo, P.; Talamini, R.; Annessi, G.; Bruno, W.; Nasti, S.; Gargiulo, S.; et al. CDKN2A and MC1R analysis in amelanotic and pigmented melanoma. Melanoma Res. 2009, 19, 142-145. [CrossRef] [PubMed]

56. Moreau, J.F.; Weissfeld, J.L.; Ferris, L.K. Characteristics and survival of patients with invasive amelanotic melanoma in the USA. Melanoma Res. 2013, 23, 408-413. [CrossRef] [PubMed]

57. McClain, S.E.; Mayo, K.B.; Shada, A.L.; Smolkin, M.E.; Patterson, J.W.; Slingluff, C.L. Amelanotic melanomas presenting as red skin lesions: A diagnostic challenge with potentially lethal consequences. Int. J. Dermatol. 2012, 51, 420-426. [CrossRef] [PubMed]

58. Pouryazdanparast, P.; Brenner, A.; Haghighat, Z.; Guitart, J.; Rademaker, A.; Gerami, P. The role of 8q24 copy number gains and c-MYC expression in amelanotic cutaneous melanoma. Mod. Pathol. 2012, 25, 1221-1226. [CrossRef] [PubMed]

59. Detrixhe, A.; Libon, F.; Mansuy, M.; Nikkels-Tassoudji, N.; Rorive, A.; Arrese, J.E.; Quatresooz, P.; Reginster, M.-A.; Nikkels, A.F. Melanoma masquerading as nonmelanocytic lesions. Melanoma Res. 2016, 26, 631-634. [CrossRef] [PubMed]

60. Beyeler, M.; Dummer, R. Cutaneous melanoma: Uncommon presentations. Clin. Dermatol. 2005, 23, 587-592. [CrossRef]

61. Vernali, S.; Waxweiler, W.T.; Dillon, P.M.; Kanetsky, P.A.; Orlow, I.; Luo, L.; Busam, K.J.; Kricker, A.; Armstrong, B.K.; Anton-Culver, H.; et al. Association of Incident Amelanotic Melanoma With Phenotypic Characteristics, MC1R Status, and Prior Amelanotic Melanoma. JAMA Dermatol. 2017, 153, 1026-1031. [CrossRef]

62. Sturm, R.A.; Fox, C.; McClenahan, P.; Jagirdar, K.; Ibarrola-Villava, M.; Banan, P.; Abbott, N.C.; Ribas, G.; Gabrielli, B.; Duffy, D.L.; et al. Phenotypic characterization of nevus and tumor patterns in MITF E318K mutation carrier melanoma patients. J. Investig. Dermatol. 2014, 134, 141-149. [CrossRef]

63. Massi, D.; Pinzani, P.; Simi, L.; Salvianti, F.; De Giorgi, V.; Pizzichetta, M.A.; Mirri, F.; Steffan, A.; Orlando, C.; Santucci, M.; et al. BRAF and KIT somatic mutations are present in amelanotic melanoma. Melanoma Res. 2013, 23, 414-419. [CrossRef]

64. Palla, B.; Su, A.; Binder, S.; Dry, S. SOX10 expression distinguishes desmoplastic melanoma from its histologic mimics. Am. J. Dermatopathol. 2013, 35, 576-581. [CrossRef]

65. Chen, L.L.; Jaimes, N.; Barker, C.A.; Busam, K.J.; Marghoob, A.A. Desmoplastic melanoma: A review. J. Am. Acad. Dermatol. 2013, 68, 825-833. [CrossRef] [PubMed]

66. Hawkins, W.G.; Busam, K.J.; Ben-Porat, L.; Panageas, K.S.; Coit, D.G.; Gyorki, D.E.; Linehan, D.C.; Brady, M.S. Desmoplastic melanoma: A pathologically and clinically distinct form of cutaneous melanoma. Ann. Surg. Oncol. 2005, 12, 207-213. [CrossRef] [PubMed]

67. Shain, A.H.; Garrido, M.; Botton, T.; Talevich, E.; Yeh, I.; Sanborn, J.Z.; Chung, J.; Wang, N.J.; Kakavand, H.; Mann, G.J.; et al. Exome sequencing of desmoplastic melanoma identifies recurrent NFKBIE promoter mutations and diverse activating mutations in the MAPK pathway. Nat. Genet. 2015, 47, 1194-1199. [CrossRef] [PubMed]

68. Hayward, N.K.; Wilmott, J.S.; Waddell, N.; Johansson, P.A.; Field, M.A.; Nones, K.; Patch, A.-M.; Kakavand, H.; Alexandrov, L.B.; Burke, H.; et al. Whole-genome landscapes of major melanoma subtypes. Nature 2017, 545, 175-180. [CrossRef] [PubMed]

69. Boussemart, L.; Johnson, A.; Schrock, A.B.; Pal, S.K.; Frampton, G.M.; Fabrizio, D.; Chalmers, Z.; Lotem, M.; Gibney, G.; Russell, J.; et al. Tumor mutational burden and response to programmed cell death protein 1 inhibitors in a case series of patients with metastatic desmoplastic melanoma. J. Am. Acad. Dermatol. 2019, 80, 1780-1782. [CrossRef] [PubMed]

70. Barnhill, R.L. The Spitzoid lesion: Rethinking Spitz tumors, atypical variants, "Spitzoid melanoma" and risk assessment. Mod. Pathol. 2006, 19 (Suppl. 2), S21-S33. [CrossRef]

71. Lallas, A.; Kyrgidis, A.; Ferrara, G.; Kittler, H.; Apalla, Z.; Castagnetti, F.; Longo, C.; Moscarella, E.; Piana, S.; Zalaudek, I.; et al. Atypical Spitz tumours and sentinel lymph node biopsy: A systematic review. Lancet Oncol. 2014, 15, e178-e183. [CrossRef]

72. Ghazi, B.; Carlson, G.W.; Murray, D.R.; Gow, K.W.; Page, A.; Durham, M.; Kooby, D.A.; Parker, D.; Rapkin, L.; Lawson, D.H.; et al. Utility of lymph node assessment for atypical spitzoid melanocytic neoplasms. Ann. Surg. Oncol. 2010, 17, 2471-2475. [CrossRef] 
73. Elder, D.E.; Bastian, B.C.; Cree, I.A.; Massi, D.; Scolyer, R.A. The 2018 World Health Organization Classification of Cutaneous, Mucosal, and Uveal Melanoma: Detailed Analysis of 9 Distinct Subtypes Defined by Their Evolutionary Pathway. Arch. Pathol. Lab. Med. 2020, 144, 500-522. [CrossRef]

74. Wiesner, T.; He, J.; Yelensky, R.; Esteve-Puig, R.; Botton, T.; Yeh, I.; Lipson, D.; Otto, G.; Brennan, K.; Murali, R.; et al. Kinase fusions are frequent in Spitz tumours and spitzoid melanomas. Nat. Commun. 2014, 5, 3116. [CrossRef]

75. Lazova, R.; Pornputtapong, N.; Halaban, R.; Bosenberg, M.; Bai, Y.; Chai, H.; Krauthammer, M. Spitz nevi and Spitzoid melanomas: Exome sequencing and comparison with conventional melanocytic nevi and melanomas. Mod. Pathol. 2017, 30, 640-649. [CrossRef] [PubMed]

76. Raghavan, S.S.; Peternel, S.; Mully, T.W.; North, J.P.; Pincus, L.B.; LeBoit, P.E.; McCalmont, T.H.; Bastian, B.C.; Yeh, I. Spitz melanoma is a distinct subset of spitzoid melanoma. Mod. Pathol. 2020, 33, 1122-1134. [CrossRef] [PubMed]

77. Farah, M.; Nagarajan, P.; Curry, J.L.; Tang, Z.; Kim, T.-B.; Aung, P.P.; Torres-Cabala, C.A.; Eterovic, A.K.; Wargo, J.A.; Prieto, V.G.; et al. Spitzoid melanoma with histopathological features of ALK gene rearrangement exhibiting ALK copy number gain: A novel mechanism of ALK activation in spitzoid neoplasia. Br. J. Dermatol. 2019, 180, 404-408. [CrossRef]

78. Research, A.A. Potentially Actionable MAP3K8 Alterations Are Common in Spitzoid Melanoma. Cancer Discov. 2019, 9, 574. [CrossRef]

79. Ho, A.L.; Hanna, G.J.; Scholz, C.R.; Gualberto, A.; Park, S.H. Preliminary activity of tipifarnib in tumors of the head and neck, salivary gland and urothelial tract with HRAS mutations. J. Clin. Oncol. 2020, $38,6504$. [CrossRef]

80. Bellew, S.; Del Rosso, J.Q.; Kim, G.K. Skin cancer in asians: Part 2: Melanoma. J. Clin. Aesthetic Dermatol. 2009, 2, 34-36.

81. Dika, E.; Veronesi, G.; Altimari, A.; Riefolo, M.; Ravaioli, G.M.; Piraccini, B.M.; Lambertini, M.; Campione, E.; Gruppioni, E.; Fiorentino, M.; et al. BRAF, KIT, and NRAS Mutations of Acral Melanoma in White Patients. Am. J. Clin. Pathol. 2020, 153, 664-671. [CrossRef] [PubMed]

82. Moon, K.R.; Choi, Y.D.; Kim, J.M.; Jin, S.; Shin, M.-H.; Shim, H.-J.; Lee, J.-B.; Yun, S.J. Genetic Alterations in Primary Acral Melanoma and Acral Melanocytic Nevus in Korea: Common Mutated Genes Show Distinct Cytomorphological Features. J. Investig. Dermatol. 2018, 138, 933-945. [CrossRef] [PubMed]

83. Woodman, S.E.; Davies, M.A. Targeting KIT in melanoma: A paradigm of molecular medicine and targeted therapeutics. Biochem. Pharmacol. 2010, 80, 568-574. [CrossRef]

84. Yu, S.; Xu, T.; Dai, J.; Ma, M.; Tang, H.; Chi, Z.; Si, L.; Cui, C.; Sheng, X.; Kong, Y.; et al. TERT copy gain predicts the outcome of high-dose interferon $\alpha$-2b therapy in acral melanoma. OncoTargets Ther. 2018, 11, 4097-4104. [CrossRef]

85. Yu, J.; Yu, J.; Wu, X.; Guo, Q.; Yin, T.; Cheng, Z.; Dai, J.; Kong, Y.; Guo, J. The TERT copy number gain is sensitive to telomerase inhibitors in human melanoma. Clin. Sci. 2020, 134, 193-205. [CrossRef] [PubMed]

86. Kim, K.B.; Eton, O.; Davis, D.W.; Frazier, M.L.; McConkey, D.J.; Diwan, A.H.; Papadopoulos, N.E.; Bedikian, A.Y.; Camacho, L.H.; Ross, M.I.; et al. Phase II trial of imatinib mesylate in patients with metastatic melanoma. Br. J. Cancer 2008, 99, 734-740. [CrossRef] [PubMed]

87. Guo, J.; Si, L.; Kong, Y.; Flaherty, K.T.; Xu, X.; Zhu, Y.; Corless, C.L.; Li, L.; Li, H.; Sheng, X.; et al. Phase II, open-label, single-arm trial of imatinib mesylate in patients with metastatic melanoma harboring c-Kit mutation or amplification. J. Clin. Oncol. 2011, 29, 2904-2909. [CrossRef]

88. Carvajal, R.D.; Antonescu, C.R.; Wolchok, J.D.; Chapman, P.B.; Roman, R.-A.; Teitcher, J.; Panageas, K.S.; Busam, K.J.; Chmielowski, B.; Lutzky, J.; et al. KIT as a therapeutic target in metastatic melanoma. JAMA 2011, 305, 2327-2334. [CrossRef] [PubMed]

89. Hodi, F.S.; Corless, C.L.; Giobbie-Hurder, A.; Fletcher, J.A.; Zhu, M.; Marino-Enriquez, A.; Friedlander, P.; Gonzalez, R.; Weber, J.S.; Gajewski, T.F.; et al. Imatinib for melanomas harboring mutationally activated or amplified KIT arising on mucosal, acral, and chronically sun-damaged skin. J. Clin. Oncol. 2013, 31, 3182-3190. [CrossRef] [PubMed]

90. Cho, J.H.; Kim, K.M.; Kwon, M.; Kim, J.H.; Lee, J. Nilotinib in patients with metastatic melanoma harboring KIT gene aberration. Investig. New Drugs 2012, 30, 2008-2014. [CrossRef] 
91. Carvajal, R.D.; Lawrence, D.P.; Weber, J.S.; Gajewski, T.F.; Gonzalez, R.; Lutzky, J.; O’Day, S.J.; Hamid, O.; Wolchok, J.D.; Chapman, P.B.; et al. Phase II Study of Nilotinib in Melanoma Harboring KIT Alterations Following Progression to Prior KIT Inhibition. Clin. Cancer Res. 2015, 21, 2289-2296. [CrossRef]

92. Lee, S.J.; Kim, T.M.; Kim, Y.J.; Jang, K.-T.; Lee, H.J.; Lee, S.N.; Ahn, M.S.; Hwang, I.G.; Lee, S.; Lee, M.-H.; et al. Phase II Trial of Nilotinib in Patients With Metastatic Malignant Melanoma Harboring KIT Gene Aberration: A Multicenter Trial of Korean Cancer Study Group (UN10-06). Oncologist 2015, 20, 1312-1319. [CrossRef]

93. Guo, J.; Carvajal, R.D.; Dummer, R.; Hauschild, A.; Daud, A.; Bastian, B.C.; Markovic, S.N.; Queirolo, P.; Arance, A.; Berking, C.; et al. Efficacy and safety of nilotinib in patients with KIT-mutated metastatic or inoperable melanoma: Final results from the global, single-arm, phase II TEAM trial. Ann. Oncol. 2017, 28, 1380-1387. [CrossRef]

94. Delyon, J.; Chevret, S.; Jouary, T.; Dalac, S.; Dalle, S.; Guillot, B.; Arnault, J.-P.; Avril, M.-F.; Bedane, C.; Bens, G.; et al. STAT3 Mediates Nilotinib Response in KIT-Altered Melanoma: A Phase II Multicenter Trial of the French Skin Cancer Network. J. Investig. Dermatol. 2018, 138, 58-67. [CrossRef]

95. Kalinsky, K.; Lee, S.; Rubin, K.M.; Lawrence, D.P.; Iafrarte, A.J.; Borger, D.R.; Margolin, K.A.; Leitao, M.M.; Tarhini, A.A.; Koon, H.B.; et al. A phase 2 trial of dasatinib in patients with locally advanced or stage IV mucosal, acral, or vulvovaginal melanoma: A trial of the ECOG-ACRIN Cancer Research Group (E2607). Cancer 2017, 123, 2688-2697. [CrossRef] [PubMed]

96. Minor, D.R.; Kashani-Sabet, M.; Garrido, M.; O’Day, S.J.; Hamid, O.; Bastian, B.C. Sunitinib therapy for melanoma patients with KIT mutations. Clin. Cancer Res. 2012, 18, 1457-1463. [CrossRef] [PubMed]

97. Kaunitz, G.J.; Cottrell, T.R.; Lilo, M.; Muthappan, V.; Esandrio, J.; Berry, S.; Xu, H.; Ogurtsova, A.; Anders, R.A.; Fischer, A.H.; et al. Melanoma subtypes demonstrate distinct PD-L1 expression profiles. Lab. Investig. 2017, 97, 1063-1071. [CrossRef] [PubMed]

98. Rabbie, R.; Ferguson, P.; Molina-Aguilar, C.; Adams, D.J.; Robles-Espinoza, C.D. Melanoma subtypes: Genomic profiles, prognostic molecular markers and therapeutic possibilities. J. Pathol. 2019, 247, 539-551. [CrossRef]

99. Johnson, D.B.; Peng, C.; Abramson, R.G.; Ye, F.; Zhao, S.; Wolchok, J.D.; Sosman, J.A.; Carvajal, R.D.; Ariyan, C.E. Clinical Activity of Ipilimumab in Acral Melanoma: A Retrospective Review. Oncologist 2015, 20, 648-652. [CrossRef]

100. Shoushtari, A.N.; Munhoz, R.R.; Kuk, D.; Ott, P.A.; Johnson, D.B.; Tsai, K.K.; Rapisuwon, S.; Eroglu, Z.; Sullivan, R.J.; Luke, J.J.; et al. The efficacy of anti-PD-1 agents in acral and mucosal melanoma. Cancer 2016, 122, 3354-3362. [CrossRef]

101. Tacastacas, J.D.; Bray, J.; Cohen, Y.K.; Arbesman, J.; Kim, J.; Koon, H.B.; Honda, K.; Cooper, K.D.; Gerstenblith, M.R. Update on primary mucosal melanoma. J. Am. Acad. Dermatol. 2014, 71, 366-375. [CrossRef]

102. Patrick, R.J.; Fenske, N.A.; Messina, J.L. Primary mucosal melanoma. J. Am. Acad. Dermatol. 2007, 56, 828-834. [CrossRef]

103. Kuk, D.; Shoushtari, A.N.; Barker, C.A.; Panageas, K.S.; Munhoz, R.R.; Momtaz, P.; Ariyan, C.E.; Brady, M.S.; Coit, D.G.; Bogatch, K.; et al. Prognosis of Mucosal, Uveal, Acral, Nonacral Cutaneous, and Unknown Primary Melanoma From the Time of First Metastasis. Oncologist 2016, 21, 848-854. [CrossRef]

104. Furney, S.J.; Turajlic, S.; Stamp, G.; Nohadani, M.; Carlisle, A.; Thomas, J.M.; Hayes, A.; Strauss, D.; Gore, M.; van den Oord, J.; et al. Genome sequencing of mucosal melanomas reveals that they are driven by distinct mechanisms from cutaneous melanoma. J. Pathol. 2013, 230, 261-269. [CrossRef]

105. Hintzsche, J.D.; Gorden, N.T.; Amato, C.M.; Kim, J.; Wuensch, K.E.; Robinson, S.E.; Applegate, A.J.; Couts, K.L.; Medina, T.M.; Wells, K.R.; et al. Whole-exome sequencing identifies recurrent SF3B1 R625 mutation and comutation of NF1 and KIT in mucosal melanoma. Melanoma Res. 2017, 27, 189-199. [CrossRef] [PubMed]

106. DeMatos, P.; Tyler, D.S.; Seigler, H.F. Malignant melanoma of the mucous membranes: A review of 119 cases. Ann. Surg. Oncol. 1998, 5, 733-742. [CrossRef] [PubMed]

107. Carvajal, R.D.; Spencer, S.A.; Lydiatt, W. Mucosal melanoma: A clinically and biologically unique disease entity. J. Natl. Compr. Cancer Netw. 2012, 10, 345-356. [CrossRef] [PubMed]

108. Amin, M.B.; Edge, S.; Greene, F.; Byrd, D.R.; Brookland, R.K.; Washington, M.K.; Gershenwald, J.E.; Compton, C.C.; Hess, K.R.; Sullivan, D.C.; et al. AJCC Cancer Staging Manual, 8th ed.; Springer International Publishing, Ltd.: Chicago, IL, USA, 2017; pp. 163-167. 
109. Kelly, P.; Zagars, G.K.; Cormier, J.N.; Ross, M.I.; Guadagnolo, B.A. Sphincter-sparing local excision and hypofractionated radiation therapy for anorectal melanoma: A 20-year experience. Cancer 2011, 117, 4747-4755. [CrossRef]

110. Lian, B.; Si, L.; Cui, C.; Chi, Z.; Sheng, X.; Mao, L.; Li, S.; Kong, Y.; Tang, B.; Guo, J. Phase II randomized trial comparing high-dose IFN- $\alpha 2 \mathrm{~b}$ with temozolomide plus cisplatin as systemic adjuvant therapy for resected mucosal melanoma. Clin. Cancer Res. 2013, 19, 4488-4498. [CrossRef]

111. Lian, B.; Guo, J. Adjuvant therapy of mucosal melanoma. Chin. Clin. Oncol. 2014, 3, 33. [CrossRef]

112. Gray-Schopfer, V.; Wellbrock, C.; Marais, R. Melanoma biology and new targeted therapy. Nature 2007, 445, 851-857. [CrossRef]

113. Dumaz, N.; Jouenne, F.; Delyon, J.; Mourah, S.; Bensussan, A.; Lebbé, C. Atypical BRAF and NRAS Mutations in Mucosal Melanoma. Cancers 2019, 11, 1133. [CrossRef]

114. Bryce, A.H.; Arguello, D.; Millis, S.Z.; Bender, R.; Reddy, S.K.; Gatalica, Z.; Gonzalez, R. Multiplatform biomarker analysis on non-sun exposed mucosal melanoma. J. Clin. Oncol. 2015, 33, 9042. [CrossRef]

115. Nassar, K.W.; Tan, A.C. The mutational landscape of mucosal melanoma. Semin. Cancer Biol. 2020, 61, 139-148. [CrossRef]

116. Newell, F.; Kong, Y.; Wilmott, J.S.; Johansson, P.A.; Ferguson, P.M.; Cui, C.; Li, Z.; Kazakoff, S.H.; Burke, H.; Dodds, T.J.; et al. Whole-genome landscape of mucosal melanoma reveals diverse drivers and therapeutic targets. Nat. Commun. 2019, 10, 3163. [CrossRef]

117. Bai, X.; Mao, L.L.; Chi, Z.H.; Sheng, X.N.; Cui, C.L.; Kong, Y.; Dai, J.; Wang, X.; Li, S.M.; Tang, B.X.; et al. BRAF inhibitors: Efficacious and tolerable in BRAF-mutant acral and mucosal melanoma. Neoplasma 2017, 64, 626-632. [CrossRef]

118. Kim, H.S.; Jung, M.; Kang, H.N.; Kim, H.; Park, C.-W.; Kim, S.-M.; Shin, S.J.; Kim, S.H.; Kim, S.G.; Kim, E.K.; et al. Oncogenic BRAF fusions in mucosal melanomas activate the MAPK pathway and are sensitive to MEK/PI3K inhibition or MEK/CDK4/6 inhibition. Oncogene 2017, 36, 3334-3345. [CrossRef] [PubMed]

119. Rönnstrand, L. Signal transduction via the stem cell factor receptor/c-Kit. Cell. Mol. Life Sci. 2004, 61, 2535-2548. [CrossRef] [PubMed]

120. Beadling, C.; Jacobson-Dunlop, E.; Hodi, F.S.; Le, C.; Warrick, A.; Patterson, J.; Town, A.; Harlow, A.; Cruz, F.; Azar, S.; et al. KIT gene mutations and copy number in melanoma subtypes. Clin. Cancer Res. 2008, 14, 6821-6828. [CrossRef] [PubMed]

121. Bai, X.; Kong, Y.; Chi, Z.; Sheng, X.; Cui, C.; Wang, X.; Mao, L.; Tang, B.; Li, S.; Lian, B.; et al. MAPK Pathway and TERT Promoter Gene Mutation Pattern and Its Prognostic Value in Melanoma Patients: A Retrospective Study of 2,793 Cases. Clin. Cancer Res. 2017, 23, 6120-6127. [CrossRef]

122. Cinotti, E.; Chevallier, J.; Labeille, B.; Cambazard, F.; Thomas, L.; Balme, B.; Leccia, M.T.; D'Incan, M.; Vercherin, P.; Douchet, C.; et al. Mucosal melanoma: Clinical, histological and c-kit gene mutational profile of 86 French cases. J. Eur. Acad. Dermatol. Venereol. 2017, 31, 1834-1840. [CrossRef]

123. Toscano de Mendonça, U.B.; Cernea, C.R.; Matos, L.L.; Monteiro de Araujo Lima, R.R. Analysis of KIT gene mutations in patients with melanoma of the head and neck mucosa: A retrospective clinical report. Oncotarget 2018, 9, 22886-22894. [CrossRef]

124. Omholt, K.; Grafström, E.; Kanter-Lewensohn, L.; Hansson, J.; Ragnarsson-Olding, B.K. KIT pathway alterations in mucosal melanomas of the vulva and other sites. Clin. Cancer Res. 2011, 17, 3933-3942. [CrossRef]

125. Carlino, M.S.; Todd, J.R.; Rizos, H. Resistance to c-Kit inhibitors in melanoma: Insights for future therapies. Oncoscience 2014, 1, 423-426. [CrossRef]

126. Ablain, J.; Xu, M.; Rothschild, H.; Jordan, R.C.; Mito, J.K.; Daniels, B.H.; Bell, C.F.; Joseph, N.M.; Wu, H.; Bastian, B.C.; et al. Human tumor genomics and zebrafish modeling identify SPRED1 loss as a driver of mucosal melanoma. Science 2018, 362, 1055-1060. [CrossRef] [PubMed]

127. Lyu, J.; Song, Z.; Chen, J.; Shepard, M.J.; Song, H.; Ren, G.; Li, Z.; Guo, W.; Zhuang, Z.; Shi, Y. Whole-exome sequencing of oral mucosal melanoma reveals mutational profile and therapeutic targets. J. Pathol. 2018, 244, 358-366. [CrossRef] [PubMed]

128. Zhou, R.; Shi, C.; Tao, W.; Li, J.; Wu, J.; Han, Y.; Yang, G.; Gu, Z.; Xu, S.; Wang, Y.; et al. Analysis of Mucosal Melanoma Whole-Genome Landscapes Reveals Clinically Relevant Genomic Aberrations. Clin. Cancer Res. 2019, 25, 3548-3560. [CrossRef] [PubMed] 
129. Cirenajwis, H.; Lauss, M.; Ekedahl, H.; Törngren, T.; Kvist, A.; Saal, L.H.; Olsson, H.; Staaf, J.; Carneiro, A.; Ingvar, C.; et al. NF1-mutated melanoma tumors harbor distinct clinical and biological characteristics. Mol. Oncol. 2017, 11, 438-451. [CrossRef]

130. Sheng, X.; Kong, Y.; Li, Y.; Zhang, Q.; Si, L.; Cui, C.; Chi, Z.; Tang, B.; Mao, L.; Lian, B.; et al. GNAQ and GNA11 mutations occur in $9.5 \%$ of mucosal melanoma and are associated with poor prognosis. Eur. J. Cancer 2016, 65, 156-163. [CrossRef]

131. Lyu, J.; Wu, Y.; Li, C.; Wang, R.; Song, H.; Ren, G.; Guo, W. Mutation scanning of BRAF, NRAS, KIT, and GNAQ/GNA11 in oral mucosal melanoma: A study of 57 cases. J. Oral Pathol. Med. 2016, 45, 295-301. [CrossRef]

132. Sari, Ş.Ö.; Yilmaz, İ.; Taşkin, O.Ç.; Narli, G.; Şen, F.; Çomoğlu, Ş.; Firat, P.; Bİlgİç, B.; Yilmazbayhan, D.; Özlük, Y.; et al. BRAF, NRAS, KIT, TERT, GNAQ/GNA11 mutation profile analysis of head and neck mucosal melanomas: A study of 42 cases. Pathology 2017, 49, 55-61. [CrossRef]

133. Cosgarea, I.; Ugurel, S.; Sucker, A.; Livingstone, E.; Zimmer, L.; Ziemer, M.; Utikal, J.; Mohr, P.; Pfeiffer, C.; Pföhler, C.; et al. Targeted next generation sequencing of mucosal melanomas identifies frequent NF1 and RAS mutations. Oncotarget 2017, 8, 40683-40692. [CrossRef]

134. Quek, C.; Rawson, R.V.; Ferguson, P.M.; Shang, P.; Silva, I.; Saw, R.P.M.; Shannon, K.; Thompson, J.F.; Hayward, N.K.; Long, G.V.; et al. Recurrent hotspot SF3B1 mutations at codon 625 in vulvovaginal mucosal melanoma identified in a study of 27 Australian mucosal melanomas. Oncotarget 2019, 10, 930-941. [CrossRef]

135. Rao, R.D.; Holtan, S.G.; Ingle, J.N.; Croghan, G.A.; Kottschade, L.A.; Creagan, E.T.; Kaur, J.S.; Pitot, H.C.; Markovic, S.N. Combination of paclitaxel and carboplatin as second-line therapy for patients with metastatic melanoma. Cancer 2006, 106, 375-382. [CrossRef]

136. Hodi, F.S.; Soiffer, R.J.; Clark, J.; Finkelstein, D.M.; Haluska, F.G. Phase II study of paclitaxel and carboplatin for malignant melanoma. Am. J. Clin. Oncol. 2002, 25, 283-286. [CrossRef] [PubMed]

137. Middleton, M.R.; Grob, J.J.; Aaronson, N.; Fierlbeck, G.; Tilgen, W.; Seiter, S.; Gore, M.; Aamdal, S.; Cebon, J.; Coates, A.; et al. Randomized phase III study of temozolomide versus dacarbazine in the treatment of patients with advanced metastatic malignant melanoma. J. Clin. Oncol. 2000, 18, 158-166. [CrossRef] [PubMed]

138. Mignard, C.; Deschamps Huvier, A.; Gillibert, A.; Duval Modeste, A.B.; Dutriaux, C.; Khammari, A.; Avril, M.-F.; Kramkimel, N.; Mortier, L.; Marcant, P.; et al. Efficacy of Immunotherapy in Patients with Metastatic Mucosal or Uveal Melanoma. J. Oncol. 2018, 2018, 1-9. [CrossRef] [PubMed]

139. Hamid, O.; Robert, C.; Ribas, A.; Hodi, F.S.; Walpole, E.; Daud, A.; Arance, A.S.; Brown, E.; Hoeller, C.; Mortier, L.; et al. Antitumour activity of pembrolizumab in advanced mucosal melanoma: A post-hoc analysis of KEYNOTE-001, 002, 006. Br. J. Cancer 2018, 119, 670-674. [CrossRef]

140. Moya-Plana, A.; Herrera Gómez, R.G.; Rossoni, C.; Dercle, L.; Ammari, S.; Girault, I.; Roy, S.; Scoazec, J.-Y.; Vagner, S.; Janot, F.; et al. Evaluation of the efficacy of immunotherapy for non-resectable mucosal melanoma. Cancer Immunol. Immunother. 2019, 68, 1171-1178. [CrossRef]

141. D'Angelo, S.P.; Larkin, J.; Sosman, J.A.; Lebbé, C.; Brady, B.; Neyns, B.; Schmidt, H.; Hassel, J.C.; Hodi, F.S.; Lorigan, P.; et al. Efficacy and Safety of Nivolumab Alone or in Combination With Ipilimumab in Patients With Mucosal Melanoma: A Pooled Analysis. J. Clin. Oncol. 2017, 35, 226-235. [CrossRef]

142. Shoushtari, A.N.; Wagstaff, J.; Ascierto, P.A.; Butler, M.O.; Lao, C.D.; Marquez-Rodas, I.; Chiarion-Sileni, V.; Dummer, R.; Ferrucci, P.F.; Lorigan, P.; et al. CheckMate 067: Long-term outcomes in patients with mucosal melanoma. J. Clin. Oncol. 2020, 38, 10019. [CrossRef]

143. Johnson, D.B.; Carlson, J.A.; Elvin, J.A.; Vergilio, J.-A.; Suh, J.; Ramkissoon, S.; Daniel, S.; Fabrizio, D.; Frampton, G.M.; Ali, S.M.; et al. Landscape of genomic alterations (GA) and tumor mutational burden (TMB) in different metastatic melanoma (MM) subtypes. J. Clin. Oncol. 2017, 35, 9536. [CrossRef]

144. Johnson, B.F.; Clay, T.M.; Hobeika, A.C.; Lyerly, H.K.; Morse, M.A. Vascular endothelial growth factor and immunosuppression in cancer: Current knowledge and potential for new therapy. Expert Opin. Biol. Ther. 2007, 7, 449-460. [CrossRef]

145. Voron, T.; Colussi, O.; Marcheteau, E.; Pernot, S.; Nizard, M.; Pointet, A.-L.; Latreche, S.; Bergaya, S.; Benhamouda, N.; Tanchot, C.; et al. VEGF-A modulates expression of inhibitory checkpoints on CD8+ T cells in tumors. J. Exp. Med. 2015, 212, 139-148. [CrossRef] 
146. Motzer, R.J.; Penkov, K.; Haanen, J.; Rini, B.; Albiges, L.; Campbell, M.T.; Venugopal, B.; Kollmannsberger, C.; Negrier, S.; Uemura, M.; et al. Avelumab plus Axitinib versus Sunitinib for Advanced Renal-Cell Carcinoma. N. Engl. J. Med. 2019, 380, 1103-1115. [CrossRef] [PubMed]

147. Rini, B.I.; Plimack, E.R.; Stus, V.; Gafanov, R.; Hawkins, R.; Nosov, D.; Pouliot, F.; Alekseev, B.; Soulières, D.; Melichar, B.; et al. Pembrolizumab plus Axitinib versus Sunitinib for Advanced Renal-Cell Carcinoma. N. Engl. J. Med. 2019, 380, 1116-1127. [CrossRef] [PubMed]

148. Sheng, X.; Yan, X.; Chi, Z.; Si, L.; Cui, C.; Tang, B.; Li, S.; Mao, L.; LIAN, B.; Wang, X.; et al. Overall survival and biomarker analysis of a phase $\mathrm{Ib}$ combination study of toripalimab, a humanized IgG4 mAb against programmed death-1 (PD-1) with axitinib in patients with metastatic mucosal melanoma. J. Clin. Oncol. 2020, 38, 10007. [CrossRef]

149. Si, L.; Sheng, X.; Mao, L.; Li, C.; Wang, X.; Bai, X.; Qi, Z.H.; Chi, Z.; Cui, C.; Lian, B.; et al. A phase II study of vorolanib (CM082) in combination with toripalimab (JS001) in patients with advanced mucosal melanoma. J. Clin. Oncol. 2020, 38, 10040. [CrossRef]

150. Postow, M.A.; Luke, J.J.; Bluth, M.J.; Ramaiya, N.; Panageas, K.S.; Lawrence, D.P.; Ibrahim, N.; Flaherty, K.T.; Sullivan, R.J.; Ott, P.A.; et al. Ipilimumab for patients with advanced mucosal melanoma. Oncologist 2013, 18, 726-732. [CrossRef]

151. Del Vecchio, M.; Di Guardo, L.; Ascierto, P.A.; Grimaldi, A.M.; Sileni, V.C.; Pigozzo, J.; Ferraresi, V.; Nuzzo, C.; Rinaldi, G.; Testori, A.; et al. Efficacy and safety of ipilimumab $3 \mathrm{mg} / \mathrm{kg}$ in patients with pretreated, metastatic, mucosal melanoma. Eur. J. Cancer 2014, 50, 121-127. [CrossRef]

152. Si, L.; Zhang, X.; Shu, Y.; Pan, H.; Wu, D.; Liu, J.; Lou, F.; Mao, L.; Wang, X.; Wen, X.; et al. A Phase Ib Study of Pembrolizumab as Second-Line Therapy for Chinese Patients with Advanced or Metastatic Melanoma (KEYNOTE-151). Transl. Oncol. 2019, 12, 828-835. [CrossRef]

153. Shields, C.L.; Kaliki, S.; Shah, S.U.; Luo, W.; Furuta, M.; Shields, J.A. Iris melanoma: Features and prognosis in 317 children and adults. J. Am. Assoc. Pediatric Ophthalmol. Strabismus 2012, 16, 10-16. [CrossRef]

154. Koevary, S. Uveal Melanoma: An Updated Review. Biomed. Res. Rev. 2019, 2, 110.

155. Gallagher, R.P.; Elwood, J.M.; Rootman, J.; Spinelli, J.J.; Hill, G.B.; Threlfall, W.J.; Birdsell, J.M. Risk factors for ocular melanoma: Western Canada Melanoma Study. J. Natl. Cancer Inst. 1985, 74, 775-778.

156. Sliney, D.H. How light reaches the eye and its components. Int. J. Toxicol. 2002, 21, 501-509. [CrossRef] [PubMed]

157. Damato, E.M.; Damato, B.E. Detection and time to treatment of uveal melanoma in the United Kingdom: An evaluation of 2,384 patients. Ophthalmology 2012, 119, 1582-1589. [CrossRef] [PubMed]

158. Kujala, E.; Mäkitie, T.; Kivelä, T. Very long-term prognosis of patients with malignant uveal melanoma. Invest. Ophthalmol. Vis. Sci. 2003, 44, 4651-4659. [CrossRef] [PubMed]

159. Gomez, D.; Wetherill, C.; Cheong, J.; Jones, L.; Marshall, E.; Damato, B.; Coupland, S.E.; Ghaneh, P.; Poston, G.J.; Malik, H.Z.; et al. The Liverpool uveal melanoma liver metastases pathway: Outcome following liver resection. J. Surg. Oncol. 2014, 109, 542-547. [CrossRef]

160. Rodrigues, M.; de Koning, L.; Coupland, S.E.; Jochemsen, A.G.; Marais, R.; Stern, M.-H.; Valente, A.; Barnhill, R.; Cassoux, N.; Evans, A.; et al. So Close, yet so Far: Discrepancies between Uveal and Other Melanomas. A Position Paper from UM Cure 2020. Cancers 2019, 11, 1032. [CrossRef]

161. Van Raamsdonk, C.D.; Bezrookove, V.; Green, G.; Bauer, J.; Gaugler, L.; O’Brien, J.M.; Simpson, E.M.; Barsh, G.S.; Bastian, B.C. Frequent somatic mutations of GNAQ in uveal melanoma and blue naevi. Nature 2009, 457, 599-602. [CrossRef]

162. Feng, X.; Degese, M.S.; Iglesias-Bartolome, R.; Vaque, J.P.; Molinolo, A.A.; Rodrigues, M.; Zaidi, M.R.; Ksander, B.R.; Merlino, G.; Sodhi, A.; et al. Hippo-independent activation of YAP by the GNAQ uveal melanoma oncogene through a trio-regulated rho GTPase signaling circuitry. Cancer Cell 2014, 25, 831-845. [CrossRef]

163. Harbour, J.W. The genetics of uveal melanoma: An emerging framework for targeted therapy. Pigment Cell Melanoma Res. 2012, 25, 171-181. [CrossRef]

164. Chen, X.; Wu, Q.; Tan, L.; Porter, D.; Jager, M.J.; Emery, C.; Bastian, B.C. Combined PKC and MEK inhibition in uveal melanoma with GNAQ and GNA11 mutations. Oncogene 2014, 33, 4724-4734. [CrossRef]

165. Van Raamsdonk, C.D.; Griewank, K.G.; Crosby, M.B.; Garrido, M.C.; Vemula, S.; Wiesner, T.; Obenauf, A.C.; Wackernagel, W.; Green, G.; Bouvier, N.; et al. Mutations in GNA11 in uveal melanoma. N. Engl. J. Med. 2010, 363, 2191-2199. [CrossRef] 
166. Van Raamsdonk, C.D.; Fitch, K.R.; Fuchs, H.; de Angelis, M.H.; Barsh, G.S. Effects of G-protein mutations on skin color. Nat. Genet. 2004, 36, 961-968. [CrossRef] [PubMed]

167. Moore, A.R.; Ceraudo, E.; Sher, J.J.; Guan, Y.; Shoushtari, A.N.; Chang, M.T.; Zhang, J.Q.; Walczak, E.G.; Kazmi, M.A.; Taylor, B.S.; et al. Recurrent activating mutations of G-protein-coupled receptor CYSLTR2 in uveal melanoma. Nat. Genet. 2016, 48, 675-680. [CrossRef]

168. Spagnolo, F.; Caltabiano, G.; Queirolo, P. Uveal melanoma. Cancer Treat. Rev. 2012, 38, 549-553. [CrossRef]

169. Carvajal, R.D.; Sosman, J.A.; Quevedo, J.F.; Milhem, M.M.; Joshua, A.M.; Kudchadkar, R.R.; Linette, G.P.; Gajewski, T.F.; Lutzky, J.; Lawson, D.H.; et al. Effect of selumetinib vs chemotherapy on progression-free survival in uveal melanoma: A randomized clinical trial. JAMA 2014, 311, 2397-2405. [CrossRef]

170. Carvajal, R.D.; Piperno-Neumann, S.; Kapiteijn, E.; Chapman, P.B.; Frank, S.; Joshua, A.M.; Piulats, J.M.; Wolter, P.; Cocquyt, V.; Chmielowski, B.; et al. Selumetinib in Combination With Dacarbazine in Patients With Metastatic Uveal Melanoma: A Phase III, Multicenter, Randomized Trial (SUMIT). J. Clin. Oncol. 2018, 36, 1232-1239. [CrossRef] [PubMed]

171. Shoushtari, A.N.; Kudchadkar, R.R.; Panageas, K.; Murthy, R.K.; Jung, M.; Shah, R.; O’Donnell, B.; Khawaja, T.T.; Shames, Y.; Prempeh-Keteku, N.A.; et al. A randomized phase 2 study of trametinib with or without GSK2141795 in patients with advanced uveal melanoma. J. Clin. Oncol. 2016, 34, 9511. [CrossRef]

172. Luke, J.J.; Callahan, M.K.; Postow, M.A.; Romano, E.; Ramaiya, N.; Bluth, M.; Giobbie-Hurder, A.; Lawrence, D.P.; Ibrahim, N.; Ott, P.A.; et al. Clinical activity of ipilimumab for metastatic uveal melanoma: A retrospective review of the Dana-Farber Cancer Institute, Massachusetts General Hospital, Memorial Sloan-Kettering Cancer Center, and University Hospital of Lausanne experience. Cancer 2013, 119, 3687-3695. [CrossRef]

173. Piulats Rodriguez, J.M.; Ochoa de Olza, M.; Codes, M.; Lopez-Martin, J.A.; Berrocal, A.; García, M.; Gurpide, A.; Homet, B.; Martin-Algarra, S. Phase II study evaluating ipilimumab as a single agent in the first-line treatment of adult patients (Pts) with metastatic uveal melanoma (MUM): The GEM-1 trial. J. Clin. Oncol. 2014, 32, 9033. [CrossRef]

174. Zimmer, L.; Vaubel, J.; Mohr, P.; Hauschild, A.; Utikal, J.; Simon, J.; Garbe, C.; Herbst, R.; Enk, A.; Kämpgen, E.; et al. Phase II DeCOG-study of ipilimumab in pretreated and treatment-naïve patients with metastatic uveal melanoma. PLoS ONE 2015, 10, e0118564. [CrossRef]

175. Joshua, A.M.; Monzon, J.G.; Mihalcioiu, C.; Hogg, D.; Smylie, M.; Cheng, T. A phase 2 study of tremelimumab in patients with advanced uveal melanoma. Melanoma Res. 2015, 25, 342-347. [CrossRef]

176. Tsai, K.K.; Shoushtari, A.N.; Munhoz, R.R.; Eroglu, Z.; Piulats, J.M.; Ott, P.A.; Johnson, D.B.; Hwang, J.; Daud, A.; Sosman, J.A.; et al. Efficacy and safety of programmed death receptor-1 (PD-1) blockade in metastatic uveal melanoma (UM). J. Clin. Oncol. 2016, 34, 9507. [CrossRef]

177. Piulats, J.M.; De La Cruz-Merino, L.; Curiel Garcia, M.T.; Berrocal, A.; Alonso-Carrión, L.; Espinosa, E.; López Castro, R.; Rodriguez-Abreu, D.; Luna Fra, P.; Martin-Algarra, S. Phase II multicenter, single arm, open label study of nivolumab (NIVO) in combination with ipilimumab (IPI) as first line in adult patients (pts) with metastatic uveal melanoma (MUM): GEM1402 NCT02626962. J. Clin. Oncol. 2017, 35, 9533. [CrossRef]

178. Scheulen, M.E.; Kaempgen, E.; Keilholz, U.; Heinzerling, L.; Ochsenreither, S.; Abendroth, A.; Hilger, R.A.; Grubert, M.; Wetter, A.; Guberina, N.; et al. STREAM: A randomized discontinuation, blinded, placebo-controlled phase II study of sorafenib (S) treatment of chemonaïve patients (pts) with metastatic uveal melanoma (MUM). J. Clin. Oncol. 2017, 35, 9511. [CrossRef]

179. Patel, S.; Lewis, K.D.; Olencki, T.; Hernandez-Aya, L.; Joseph, R.; Williamson, S.; Chandra, S.; Shirai, K.; Moscow, J. A phase II study of glembatumumab vedotin for metastatic uveal melanoma. In Proceedings of the SMR Congress, Brisbane, Australia, 18-21 October 2017; p. 194.

180. Sato, T.; Nathan, P.D.; Hernandez-Aya, L.; Sacco, J.J.; Orloff, M.M.; Visich, J.; Little, N.; Hulstine, A.-M.; Coughlin, C.M.; Carvajal, R.D. Redirected T cell lysis in patients with metastatic uveal melanoma with gp100-directed TCR IMCgp100: Overall survival findings. J. Clin. Oncol. 2018, 36, 9521. [CrossRef]

181. Castet, F.; Garcia-Mulero, S.; Sanz-Pamplona, R.; Cuellar, A.; Casanovas, O.; Caminal, J.M.; Piulats, J.M. Uveal Melanoma, Angiogenesis and Immunotherapy, Is There Any Hope? Cancers 2019, 11, 834. [CrossRef] [PubMed]

182. Harbour, J.W.; Onken, M.D.; Roberson, E.D.O.; Duan, S.; Cao, L.; Worley, L.A.; Council, M.L.; Matatall, K.A.; Helms, C.; Bowcock, A.M. Frequent mutation of BAP1 in metastasizing uveal melanomas. Science 2010, 330, 1410-1413. [CrossRef] 
183. Rai, K.; Pilarski, R.; Boru, G.; Rehman, M.; Saqr, A.H.; Massengill, J.B.; Singh, A.; Marino, M.J.; Davidorf, F.H.; Cebulla, C.M.; et al. Germline BAP1 alterations in familial uveal melanoma. Genes. Chromosom. Cancer 2017, 56, 168-174. [CrossRef]

184. Pilarski, R.; Rai, K.; Cebulla, C.; Abdel-Rahman, M. BAP1 Tumor Predisposition Syndrome. In GeneReviews ${ }^{\circledR}$; Adam, M.P., Ardinger, H.H., Pagon, R.A., Wallace, S.E., Bean, L.J., Stephens, K., Amemiya, A., Eds.; University of Washington: Seattle, WA, USA, 1993.

185. Furney, S.J.; Pedersen, M.; Gentien, D.; Dumont, A.G.; Rapinat, A.; Desjardins, L.; Turajlic, S.; Piperno-Neumann, S.; de la Grange, P.; Roman-Roman, S.; et al. SF3B1 mutations are associated with alternative splicing in uveal melanoma. Cancer Discov. 2013, 3, 1122-1129. [CrossRef]

186. Martin, M.; Maßhöfer, L.; Temming, P.; Rahmann, S.; Metz, C.; Bornfeld, N.; van de Nes, J.; Klein-Hitpass, L.; Hinnebusch, A.G.; Horsthemke, B.; et al. Exome sequencing identifies recurrent somatic mutations in EIF1AX and SF3B1 in uveal melanoma with disomy 3. Nat. Genet. 2013, 45, 933-936. [CrossRef]

187. Harbour, J.W.; Roberson, E.D.O.; Anbunathan, H.; Onken, M.D.; Worley, L.A.; Bowcock, A.M. Recurrent mutations at codon 625 of the splicing factor SF3B1 in uveal melanoma. Nat. Genet. 2013, 45, 133-135. [CrossRef]

188. Decatur, C.L.; Ong, E.; Garg, N.; Anbunathan, H.; Bowcock, A.M.; Field, M.G.; Harbour, J.W. Driver Mutations in Uveal Melanoma: Associations With Gene Expression Profile and Patient Outcomes. JAMA Ophthalmol. 2016, 134, 728-733. [CrossRef] [PubMed]

189. Yavuzyigitoglu, S.; Koopmans, A.E.; Verdijk, R.M.; Vaarwater, J.; Eussen, B.; van Bodegom, A.; Paridaens, D.; Kiliç, E.; de Klein, A. Rotterdam Ocular Melanoma Study Group Uveal Melanomas with SF3B1 Mutations: A Distinct Subclass Associated with Late-Onset Metastases. Ophthalmology 2016, 123, 1118-1128. [CrossRef] [PubMed]

190. Robertson, A.G.; Shih, J.; Yau, C.; Gibb, E.A.; Oba, J.; Mungall, K.L.; Hess, J.M.; Uzunangelov, V.; Walter, V.; Danilova, L.; et al. Integrative Analysis Identifies Four Molecular and Clinical Subsets in Uveal Melanoma. Cancer Cell 2017, 32, 204-220.e15. [CrossRef] [PubMed]

191. Jager, M.J.; Brouwer, N.J.; Esmaeli, B. The Cancer Genome Atlas Project: An Integrated Molecular View of Uveal Melanoma. Ophthalmology 2018, 125, 1139-1142. [CrossRef]

192. ClinicalTrials.gov. A Trial of Niraparib in BAP1 and Other DNA Damage Response (DDR) Deficient Neoplasms (UF-STO-ETI-001). Available online: https://clinicaltrials.gov/ct2/show/NCT03207347 (accessed on 20 July 2020).

193. Basile, M.S.; Mazzon, E.; Fagone, P.; Longo, A.; Russo, A.; Fallico, M.; Bonfiglio, V.; Nicoletti, F.; Avitabile, T.; Reibaldi, M. Immunobiology of Uveal Melanoma: State of the Art and Therapeutic Targets. Front. Oncol. 2019, 9, 1145. [CrossRef]

194. Thorsson, V.; Gibbs, D.L.; Brown, S.D.; Wolf, D.; Bortone, D.S.; Ou Yang, T.-H.; Porta-Pardo, E.; Gao, G.F.; Plaisier, C.L.; Eddy, J.A.; et al. The Immune Landscape of Cancer. Immunity 2018, 48, 812-830.e14. [CrossRef]

195. Carlring, J.; Shaif-Muthana, M.; Sisley, K.; Rennie, I.G.; Murray, A.K. Apoptotic cell death in conjunction with CD80 costimulation confers uveal melanoma cells with the ability to induce immune responses. Immunology 2003, 109, 41-48. [CrossRef]

196. Chen, P.W.; Mellon, J.K.; Mayhew, E.; Wang, S.; He, Y.G.; Hogan, N.; Niederkorn, J.Y. Uveal melanoma expression of indoleamine 2,3-deoxygenase: Establishment of an immune privileged environment by tryptophan depletion. Exp. Eye Res. 2007, 85, 617-625. [CrossRef]

197. Javed, A.; Arguello, D.; Johnston, C.; Gatalica, Z.; Terai, M.; Weight, R.M.; Orloff, M.; Mastrangelo, M.J.; Sato, T. PD-L1 expression in tumor metastasis is different between uveal melanoma and cutaneous melanoma. Immunotherapy 2017, 9, 1323-1330. [CrossRef]

198. Basile, M.S.; Mazzon, E.; Russo, A.; Mammana, S.; Longo, A.; Bonfiglio, V.; Fallico, M.; Caltabiano, R.; Fagone, P.; Nicoletti, F.; et al. Differential modulation and prognostic values of immune-escape genes in uveal melanoma. PLoS ONE 2019, 14, e0210276. [CrossRef]

199. Harper, J.; Adams, K.J.; Bossi, G.; Wright, D.E.; Stacey, A.R.; Bedke, N.; Martinez-Hague, R.; Blat, D.; Humbert, L.; Buchanan, H.; et al. An approved in vitro approach to preclinical safety and efficacy evaluation of engineered T cell receptor anti-CD3 bispecific (ImmTAC) molecules. PLoS ONE 2018, 13, e0205491. [CrossRef] [PubMed] 
200. Marincola, F.M.; Venzon, D.; White, D.; Rubin, J.T.; Lotze, M.T.; Simonis, T.B.; Balkissoon, J.; Rosenberg, S.A.; Parkinson, D.R. HLA association with response and toxicity in melanoma patients treated with interleukin 2-based immunotherapy. Cancer Res. 1992, 52, 6561-6566. [PubMed]

201. ClinicalTrials.gov (NCT03070392). Safety and Efficacy of IMCgp100 Versus Investigator Choice in Advanced Uveal Melanoma. Available online: https://clinicaltrials.gov/ct2/show/NCT03070392 (accessed on 20 July 2020).

202. Lopez, R.; Holyoke, E.D.; Moore, R.H.; Karakousis, C.P. Malignant melanoma with unknown primary site. J. Surg. Oncol. 1982, 19, 151-154. [CrossRef] [PubMed]

203. Verver, D.; van der Veldt, A.; van Akkooi, A.; Verhoef, C.; Grünhagen, D.J.; Louwman, W.J. Treatment of melanoma of unknown primary in the era of immunotherapy and targeted therapy: A Dutch population-based study. Int. J. Cancer 2020, 146, 26-34. [CrossRef] [PubMed]

204. Bae, J.M.; Choi, Y.Y.; Kim, D.S.; Lee, J.H.; Jang, H.S.; Lee, J.H.; Kim, H.; Oh, B.H.; Roh, M.R.; Nam, K.A.; et al. Metastatic melanomas of unknown primary show better prognosis than those of known primary: A systematic review and meta-analysis of observational studies. J. Am. Acad. Dermatol. 2015, 72, 59-70. [CrossRef]

205. Gos, A.; Jurkowska, M.; van Akkooi, A.; Robert, C.; Kosela-Paterczyk, H.; Koljenović, S.; Kamsukom, N.; Michej, W.; Jeziorski, A.; Pluta, P.; et al. Molecular characterization and patient outcome of melanoma nodal metastases and an unknown primary site. Ann. Surg. Oncol. 2014, 21, 4317-4323. [CrossRef]

206. Gambichler, T.; Chatzipantazi, M.; Schröter, U.; Stockfleth, E.; Gedik, C. Patients with melanoma of unknown primary show better outcome under immune checkpoint inhibitor therapy than patients with known primary: Preliminary results. Oncoimmunology 2019, 8, e1677139. [CrossRef]

207. Perng, P.; Marcus, C.; Subramaniam, R.M. (18)F-FDG PET/CT and Melanoma: Staging, Immune Modulation and Mutation-Targeted Therapy Assessment, and Prognosis. Am. J. Roentgenol. 2015, 205, 259-270. [CrossRef]

208. Henderson, F.; Johnston, H.R.; Badrock, A.P.; Jones, E.A.; Forster, D.; Nagaraju, R.T.; Evangelou, C.; Kamarashev, J.; Green, M.; Fairclough, M.; et al. Enhanced Fatty Acid Scavenging and Glycerophospholipid Metabolism Accompany Melanocyte Neoplasia Progression in Zebrafish. Cancer Res. 2019, 79, $2136-2151$. [CrossRef]

209. Faillace, W.J.; Okawara, S.H.; McDonald, J.V. Neurocutaneous melanosis with extensive intracerebral and spinal cord involvement. Report of two cases. J. Neurosurg. 1984, 61, 782-785. [CrossRef]

210. Padilla-Vázquez, F.; Escobar-de la Garma, V.H.; Ayala-Arcipreste, A.; Mendizábal-Guerra, R.; Cuesta-Mejía, T. Melanocytoma and meningeal melanocytosis, similar but different lesions. Cirugía y Circ. 2017, 85, 273-278. [CrossRef]

211. Garbacz, T.; Osuchowski, M.; Bartosik-Psujek, H. Primary diffuse meningeal melanomatosis-A rare form of meningeal melanoma: Case report. BMC Neurol. 2019, 19, 271. [CrossRef] [PubMed]

212. Mondal, S.; Pradhan, R.; Pal, S.; Bhattacharya, S.; Banerjee, A.; Bhattacharyya, D. Primary intracranial malignant melanoma in an adolescent girl: A case report. Clin. Cancer Investig. J. 2016, 5, 551-553.

213. Zhang, S.; Wang, W.; Su, X.; Tan, Q.; Sun, H.; Liu, Z.; Chen, N.; Gong, Q.; Yue, Q. Amelanotic Meningeal Melanoma with Leptomeningeal Dissemination: A Case Report and Systematic Literature Review. World Neurosurg. 2019, 122, 229-239. [CrossRef] [PubMed]

214. Larson, T.C.; Houser, O.W.; Onofrio, B.M.; Piepgras, D.G. Primary spinal melanoma. J. Neurosurg. 1987, 66, 47-49. [CrossRef]

215. Küsters-Vandevelde, H.V.N.; Germans, M.R.; Rabbie, R.; Rashid, M.; Ten Broek, R.; Blokx, W.A.M.; Prinsen, C.F.M.; Adams, D.J.; Ter Laan, M. Whole-exome sequencing of a meningeal melanocytic tumour reveals activating CYSLTR2 and EIF1AX hotspot mutations and similarities to uveal melanoma. Brain Tumor Pathol. 2018, 35, 127-130. [CrossRef]

216. Fujimori, K.; Sakai, K.; Higashiyama, F.; Oya, F.; Maejima, T.; Miyake, T. Primary central nervous system malignant melanoma with leptomeningeal melanomatosis: A case report and review of the literature. Neurosurg. Rev. 2018, 41, 333-339. [CrossRef]

217. El Habnouni, C.; Bléchet, C.; Bens, G. Pembrolizumab for primary malignant melanoma of the central nervous system. J. Neurooncol. 2018, 139, 225-227. [CrossRef]

218. Cassarino, D.S.; Cabral, E.S.; Kartha, R.V.; Swetter, S.M. Primary dermal melanoma: Distinct immunohistochemical findings and clinical outcome compared with nodular and metastatic melanoma. Arch. Dermatol. 2008, 144, 49-56. [CrossRef] 
219. Teow, J.; Chin, O.; Hanikeri, M.; Wood, B.A. Primary dermal melanoma: A West Australian cohort. ANZ J. Surg. 2015, 85, 664-667. [CrossRef]

220. Harris, C.G.; Lo, S.; Ahmed, T.; Scolyer, R.A.; Ferguson, P.M.; Karim, R.Z.; Lam, T.K.; Lee, K.K.; Shannon, K.F.; Spillane, A.J.; et al. Primary dermal melanoma: Clinical behaviour, prognosis and treatment. Eur. J. Surg. Oncol. 2020, 20. [CrossRef] [PubMed]

221. Gershenwald, J.E.; Scolyer, R.A.; Hess, K.R.; Sondak, V.K.; Long, G.V.; Ross, M.I.; Lazar, A.J.; Faries, M.B.; Kirkwood, J.M.; McArthur, G.A.; et al. Melanoma staging: Evidence-based changes in the American Joint Committee on Cancer eighth edition cancer staging manual. Cancer J. Clin. 2017, 67, 472-492. [CrossRef] [PubMed]

222. Ohashi, K.; Kato, Y.; Kanno, J.; Kasuga, T. Melanocytes and melanosis of the oesophagus in Japanese subjects-Analysis of factors effecting their increase. Virchows Arch. A Pathol. Anat. Histopathol. 1990, 417, 137-143. [CrossRef] [PubMed]

223. Schizas, D.; Mylonas, K.S.; Bagias, G.; Mastoraki, A.; Ioannidi, M.; Kanavidis, P.; Hasemaki, N.; Karavokyros, I.; Theodorou, D.; Liakakos, T. Esophageal melanoma: A systematic review and exploratory recurrence and survival analysis. Dis. Esophagus 2019, 32, doz083. [CrossRef]

224. Caldwell, C.B.; Bains, M.S.; Burt, M. Unusual malignant neoplasms of the esophagus. Oat cell carcinoma, melanoma, and sarcoma. J. Thorac. Cardiovasc. Surg. 1991, 101, 100-107. [CrossRef]

225. Gao, S.; Li, J.; Feng, X.; Shi, S.; He, J. Characteristics and Surgical Outcomes for Primary Malignant Melanoma of the Esophagus. Sci. Rep. 2016, 6, 23804. [CrossRef]

226. Hashimoto, T.; Makino, T.; Yamasaki, M.; Tanaka, K.; Miyazaki, Y.; Takahashi, T.; Kurokawa, Y.; Motoori, M.; Kimura, Y.; Nakajima, K.; et al. Clinicopathological characteristics and survival of primary malignant melanoma of the esophagus. Oncol. Lett. 2019, 18, 1872-1880. [CrossRef]

227. HE, Y.; MOU, J.; LUO, D.; GAO, B.; WEN, Y. Primary malignant melanoma of the breast: A case report and review of the literature. Oncol. Lett. 2014, 8, 238-240. [CrossRef]

228. Williams, S.A.; Ehlers, R.A.; Hunt, K.K.; Yi, M.; Kuerer, H.M.; Singletary, S.E.; Ross, M.I.; Feig, B.W.; Symmans, W.F.; Meric-Bernstam, F. Metastases to the breast from nonbreast solid neoplasms: Presentation and determinants of survival. Cancer 2007, 110, 731-737. [CrossRef]

229. Rassouli, M.; Voutsadakis, I.A. Primary Noncutaneous Malignant Melanoma of the Breast. Breast J. 2016, 22, 688-691. [CrossRef]

230. Koh, J.; Lee, J.; Jung, S.Y.; Kang, H.S.; Yun, T.; Kwon, Y. Primary Malignant Melanoma of the Breast: A Report of Two Cases. J. Pathol. Transl. Med. 2019, 53, 119-124. [CrossRef] [PubMed]

231. Deng, S.; Sun, X.; Zhu, Z.; Lu, J.; Wen, G.; Chang, X.; Gao, H.; Hua, Y.; Wang, L.; Gao, J. Primary malignant melanoma of the lung: A case report and literature review. BMC Pulm. Med. 2020, 20, 1-5. [CrossRef] [PubMed]

232. Painter, C.A.; Jain, E.; Tomson, B.N.; Dunphy, M.; Stoddard, R.E.; Thomas, B.S.; Damon, A.L.; Shah, S.; Kim, D.; Gómez Tejeda Zañudo, J.; et al. The Angiosarcoma Project: Enabling genomic and clinical discoveries in a rare cancer through patient-partnered research. Nat. Med. 2020, 26, 181-187. [CrossRef]

233. Kee, D.; Kondrashova, O.; Ananda, S.; Brown, M.P.; Cohen, P.A.; Dean, A.; Desai, J.; Fellowes, A.; Fox, S.B.; Hadley, A.; et al. NOMINATOR: Feasibility of genomic testing of rare cancers to match cancer to treatment. J. Clin. Oncol. 2020, 38, 103. [CrossRef]

(C) 2020 by the authors. Licensee MDPI, Basel, Switzerland. This article is an open access article distributed under the terms and conditions of the Creative Commons Attribution (CC BY) license (http://creativecommons.org/licenses/by/4.0/). 